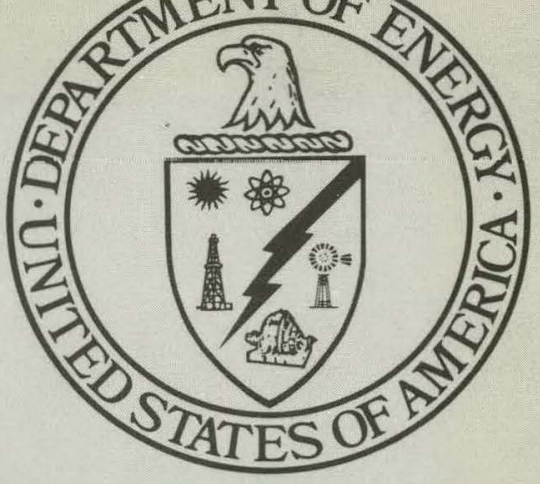

FEASIBILITY OF A CONTINUOUS SURFACE MINING MACHINE USING IMPACT BREAKERS

Phase I Report

Contractor-Foster-Miller Associates, Inc.

April 1980

Contract No. AC01-79ET-14270

\section{April 1980}

\section{Ben - 62 \\ NT/S.2S}

Contract No. AC01-79ET-14270

\title{
$\rightarrow$ and
}

\section{U. S. Department of Energy}

Assistant Secretary for Fossil Energy Office of Coal Mining 


\section{DISCLAIMER}

This report was prepared as an account of work sponsored by an agency of the United States Government. Neither the United States Government nor any agency Thereof, nor any of their employees, makes any warranty, express or implied, or assumes any legal liability or responsibility for the accuracy, completeness, or usefulness of any information, apparatus, product, or process disclosed, or represents that its use would not infringe privately owned rights. Reference herein to any specific commercial product, process, or service by trade name, trademark, manufacturer, or otherwise does not necessarily constitute or imply its endorsement, recommendation, or favoring by the United States Government or any agency thereof. The views and opinions of authors expressed herein do not necessarily state or reflect those of the United States Government or any agency thereof. 


\section{DISCLAIMER}

Portions of this document may be illegible in electronic image products. Images are produced from the best available original document. 


\section{DISCLAIMER}

"This book was prepared as an account of work sponsored by an agency of the United States Government. Neither the United States Government nor any agency thereof, nor any of their employees, makes any warranty, express or implied, or assumes any legal liability or responsibility for the accuracy, completeness, or usefulness of any information, apparatus, product, or process disclosed, or represents that its use would not infringe privately owned rights. Reference herein to any specific commercial product, process, or service by trade name, trademark, manufacturer, or otherwise, does not necessarily constitute or imply its endorsement, recommendation, or favoring by the United States Government or any agency thereof. The views and opinions of authors expressed herein do not necessarily state or reflect those of the United States Government or any agency thereof."

This report has been reproduced directly from the best available copy.

Available from the National Technical Information Service, U. S. Department of Commerce, Springfield, Virginia 22161.

Price: Paper Copy $\$ 8.00$

Microfiche $\$ 3.50$ 
F'EASIBILITY OF A CONTINUOUS SURFACE MINING MACHINE USING IMPACT BREAKERS

PHASE I REPORT

FOR THE PERIOD

1 OCTOBER 1979 - 31 MARCH 1980

ALLAN T. FISK

ROGER. J. SIMPSON

FOSTER-MILLER ASSOCIATES, INC. 350 SECOND AVENUE

WALTHAM， MASSACHUSETTS 02154

$$
\text { DATE PUBLISHED - APRIL } 1980
$$

Prepared Under

Contract No. DE-ACOI-79ET-14270

U.S. DEPARTMENT OF ENERGY

Assistant Secretary for Energy Technology

Division of Fossil Fuel Extraction

Mining Research and Development 
TABLE OF CONTENTS

A.BSTRA.CT

1. TASK NO. I - SELECTION OF FIELD SITES FOR PARAMETRIC TESTS

1.1 Mine Visits

1.2 Design Requirements of a Full Size Machine

1.3 Factors Affecting Machine Performance

2. TASK 2 - SELECT IMPACT BREAKERS, FOR FIELD TESTING 8

2.1 General Review of Hammer Data ... . 8

2.2 Final Selection 8

2.3 Impactors - Principles and Differences in 15

2.4 Hammer Calibration 17

3. TASK 3 - DESIGN PROTOTYPE IMPACTOR ARRAY TEST SYSTEM 20

4. TASTK 4 - PREPARE PARAMETRIC TEST PLAN 36

4.1 Test Objectives 36

4.2 Test Plan Summary . . . . 36

4.3 Field Equipment . . . . . . . 36

4.4 Instrumentation $\quad 39$

5. SUMMARY AND CONCLUSIONS $\quad 42$

LIST OF APPENDIXES

A - TECHNICAL CLARIFICATION OF FMA PROPOSAL $\quad \because \cdots \quad 43$

B - TEST MATRIX 50

C - REPORTS ON MINE VISITS 58 


\section{LIST OF ILIUSTRATIONS}

Figure

1

2

3

4

5

6

7

8

9

10

11

3.2

13

14

15

16

17

A -1

A-2
Joy. HEFTI Operating Principle

Contech Nutcracker Operating Principle

Contech HD-10 Parts Breakdown

Dimensional Comparison of Joy $411 \mathrm{~A}$ and cuntech $\mathrm{HU}-10$

Equal Impulse at the Same Blow Encrgy

SAM Test Vehicle.

Impact Hammer Array Test Vehicle

DOE-7953 SKOL

DOE-7953 SKO2

DOE-79.53 SKO3

DOE-7953 SKO4

DOE -7953 SKO5

DOE-7953 SKO6

Hydraulic Schematic

Bobcat 310

stanley sk-58 sinkor Drill

Firing selector Schematic

A study of the Dynamic Strength and Fracture Properties of Rock

Relationship of Excavation Energy to Strain

Rate $\underline{\text { Page }}$

12

13

14

16

18

21

22

23

25

27

29

31

33

35

37

38

40

45

46 


\section{LIST OF. TPEIES}

\section{Table}

1.

2

$B-1$

$\mathrm{B}-2$
Impact Hammer Comparative: Data Data Sheet Joy 4 lia HEFTI:Data. .

Comparison of Deptins of Cut Comparison of Tests 3 and 4
Page

9

11

53

55 


\section{ABSTRACT}

This is the first phase report of the efforts to evaluate the feasibility of excavating coal and overburden from surface mines using impact breakers. Phase I is divided into four task groups. Those tasks are as follows:
a. Task No. 1 - Selection of Field Sites for Parametric 'lests
b. Task No. 2 - Selection of Impact Hammers for Field Testing
c. Task No. 3 - Design Test System
d. Task No. 4 - Prepare Parametric Test Plan

A detailed description and accounting of each task is given in the body of this report.

Included as appendices to this report are the FMA internal reports on the individual mines visited. These reports are the basis of test site selection. 


\section{TASK NO. 1 - SELECTION OF FIELD SITES \\ FOR PARAMETRIC TESTS}

\subsection{Mine Visits}

Eight western surface mines were visited in Montana, wyoming, Colorado (3), New Mexico (2), and Indiana. The geological conditions represented the extremes of the range of conditions expected in western surface mines for both coal and overburden. As the appendices indicate, interest in the impact breaker concept varied from enthusiastic through indifferent to total rejection. Willingness to cooperate with this research was directly proportional to interest. A general concensus on the application of this concept to a mining machine was, that with present mine plans, using impact breakers to remove deep overburden was impractical and the possibility of a change to terraced mine plans with conveyor systems was futuristic. However, those mines with multiple, perhaps thinner seams, all expressed interest in the excavation of coal and parting to eliminate shallow blasting. These two points indicate that a mining machine might. better be configured in the "scraper" mode rather than the "plow" mode, and must have the ability to sump in at blind pit ends.

Mine operators were spiit on the question of tires versus tracks, as they were on whether the machine should be single purpose or an attachment to a universal power module.

It was quite apparent during our visits that the more northern mines experienced extreme climatic conditions in the winter which would probably hinder the tests, if not the testers.

Of the eight mines visited, two expressed no interest in participating in the test program. They were Energy Fuels Mine No. 1,2 and 3 at Steamboat Springs, Co and the Western Energy Rosebud Mine at Colstrip, MT.

Letters requesting a formal indication of cooperation were subsequently sent to three mines felt by FMA to be geologically suitable for test purposes. However, the AMAX Chinook Mine at Staunton, IN and Utah International's Navajo Mine at Fruitland, NM replied indicating that they were unable to participate in the test program. Only. the Colowyo Mine at Craig, co expressed an interest in a cooperative effort. At the time of this writing the mine management is pursuing the matter with the mine owners. It is worth noting at this point that Colowyo is the only mine visited which employs some terracing in its mine plan. 
Due to the low level of response from the mines most suited to our test, FMA approached the remaining two mines on the basis that a less-than-perfect test site is better than no test site. Both the Jim Bridger Mine at: Rock. Springs, WY and Utah International's Trapper Mine at Craig, Co are, at the time of writing, reviewing the test program and have promised responses shortly.

In order to gain wider industry coverage, FMA attempted to identify the unnamed mines in the original Ingersoll-Rand Report (USBM Contract. No. J0255012, dated June, 19.75 August, 1976). The FMA internal report detailing this effort is attached as an appendix. As a result, letters were sent to the AMAX Belle Ayre Mine and the Wyodak Mine, both at Giliette, WY. Each mine has promised to review the test program and to give responses in the very near future. At the time of writing, these responses are not available.

Every effort is being made by FMA to bring the matter of test site selection to a satisfactory conclusion.

\subsection{Design Requirements of a Full Size Machine}

The mine visits also served to familiarize mine operators with the concepts we are investigating, and to document their requirements in a fuli-size continuous mining machine.

Based on the observations of FMA personnel during mine site visits and comments of mine operators the following target specifications should be incorporated in a continuous mining machine to ensure effective cutting and loading of coal or rock in a typical surface mining operation.
a. Production - 1,000 to 1,500 tons/hr
b. Productivity $-5,000$ to 7,000 tons/shift
c. Operating costs - Range from $\$ .10 /$ ton for soft coal to $\$ .15 /$ ton for hard overburden
d. Size of product - As large as can be handled by sub- sequent conveyor systems to reduce dust and specific energy to a minimum
e. Environmental - Built-in sprayer to help kill dust, especially at the discharge. Operator cab must be acoustically, thermally and vibrationally isolated. to within OSHA standards. Dust filters for cab air. 
f. Rate of advance - Nominally $15 \mathrm{ft} / \mathrm{min}$ dependent on rock type and seam thickness

g. Size and weight - Turn diameter 30 to $40 \mathrm{ft}$. Ground pressure 10 to $20 \mathrm{lb} / \mathrm{in} .^{2}$. Should be able to dump $20 \mathrm{ft}$ above ground level

h. Gradeability - 16 percent minimum

i. Safety - Hydraulic hammer lock-outs to prevent accidental firing when machine is stationary or being serviced

j. Equipment - Diesel engine for mobility. Tires for high tramming speeds and shock isolation.

\subsection{Factors Affecting Machine Performance}

obviously, various naturally occurring phenomenon affect the applicability of a machine to a given situation. Any rock cutting process is extremely dependent on the geologic conditions and mining by impact hammers is no different. The efficiency of the process would be strongly influenced by the planarity, homogeneity within the cut path, and the per layer strength of the rock. The frequency, orientation and extent of fractures could profoundly affect the size of material cut, the loadings on the tool, and amount of energy wasted.

The ground bearing strength, ground water table, and stability of the highwall might be an influence if they had a negative effect on the functioning of the vehicle. Since MSHA will not allow working a highwall with a unit that is lower than the slope height, a plow-type mining machine could only be used in terraced mirie plans.

The limiting factor for a continuous mining operation would be transportation or haulage support; hence availability and planning of trucks or conveyor systems becomes essential to achieve the maximum production rate of the machine. 


\section{TASK 2 - SELECT IMPACT BREAKERS FOR FIELD TESTING}

\subsection{General Review of Hammer Data}

Seventeen hammer types were reviewed. The data, as supplied by the manufacturers is displayed in Table 1 . Three manufacturers were visited where several hammer types were demonstrated. Most significant in the data is the widely varying values of price/blow energy, blow energy/weight and apparent efficiency. Apparent efficiency is calculated from the output energy (biow energy at blow rate) versus the input energy (oil requirement). The general accuracy of these claims is questionable since one hammer gives more than it receives, a breakthrough in design and/or salesmanship. It is a fact that all claims of blow energy are based on theoretical calculation and not on test data; even the method of equitable blow energy measurement has not yet been established for the industry, and since blow energy is the basis of the three aforementioned values it is not surprising that they should vary as much as they do. Blow energy calibration is discussed in subsection 2.4. A discussion of response of rocks to impact fracture is attached as an appendix.

\subsection{Final selection}

As discussed in section 2 of the FMA proposal. we have selected a fluid tappet hammer and a conventional. hammer, both with high blow energy in order to exceed the rock fracture energy threshold, thereby reducing the specific energy of the process. Since Joy Manufacturing is the only manufacturer. of fluid tappet hammers, the Model $411 \mathrm{~A}$ (see Table 2 and Figure 1) was chosen as the hammer having the desired blow energy. This hammer has a maximum blow energy of $4000 \mathrm{ft}-\mathrm{lb}$ at $35 \mathrm{blows} / \mathrm{min}$. and can be detuned by reducing the pressure of the nitrogen accumulator.

The conventional hammer selected was the contech HD-10 (see Figures 2 and 3 ).. The following factors were considered when evaluating 13 conventional hammers:
a. Maximum blow energy
b. Blow frequency
c. Weight
d. Physical dimensions 
TABLE 1. - Impact hamner comparative data

\begin{tabular}{|c|c|c|c|c|c|c|c|c|c|c|}
\hline & 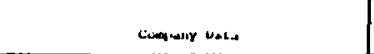 & nenal & 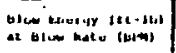 & 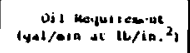 & 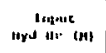 & 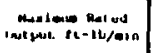 & 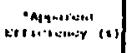 & Lien mongur reseut & rwastillary & $\therefore-\ldots$ \\
\hline 1 & 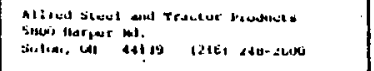 & mymas oa & 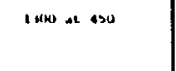 & $\therefore 2+2000$ & 20.24 & Ess, mans & $\leadsto$ & mano & r & \\
\hline$\therefore$ & 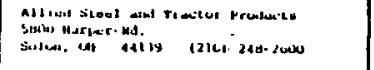 & "1puese & 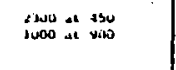 & 11-s: at swa & 9n. 54 & I,css.acen & .5 & $n_{2}$ werdurya & c & \\
\hline 1 & 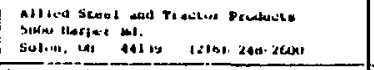 & 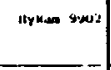 & 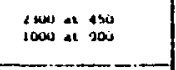 & $31-12$ is znow & $4 . .36$ & 1, us?, (us) & w & W, precturise & : & 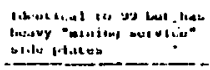 \\
\hline$\cdot$ & 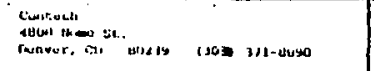 & & 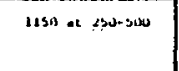 & $\therefore 25$ at zumo & 20.17 & sas, vines & bo & Air wriventerso & $:$ & \\
\hline$=1$ & 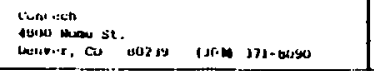 & $(4)-10$ & $2000+2 \sin 200$ & As at zowo & 32.31 & owsiven & 40 & Air yruylurye & $\therefore$ & \\
\hline$\because$ & 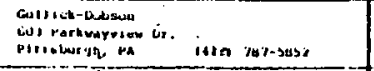 & cu sumo & $2200 \times 5$ & $18.40 \Delta 28060-28000$ & 65.14 & $1, s<0,400$ & of & 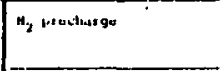 & 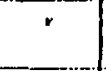 & r. \\
\hline .1 & 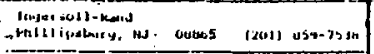 & Gillumb & $12000 \times 100$ & $10-30$ at 1700 & 8.59 & usu,owe & si & $y_{2}$ presciansyo & 4 & \\
\hline 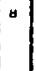 & 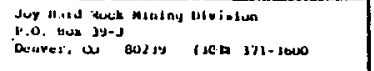 & $20: 6$ & Dewu ot 200 & 25 ac. 2500 & $s .40$ & $200,(x+a)$ & 17 & 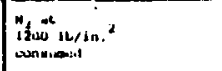 & " & 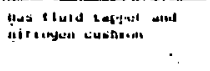 \\
\hline$y$ & 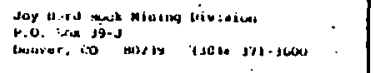 & $\cdots n$ & 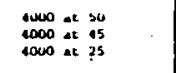 & 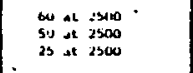 & 41.54 & swo.ow & or & 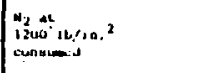 & 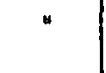 & 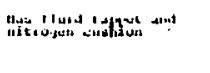 \\
\hline (in) & 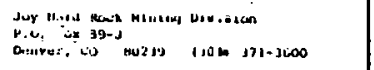 & a11. & 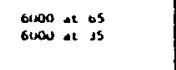 & 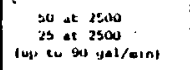 & $n ., 93$ & soo, ows & 10 & 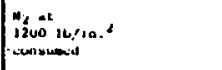 & $*$ & 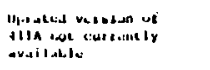 \\
\hline ai) & 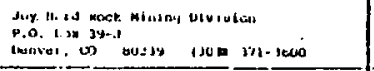 & 319 & 20, ovo we :21 & 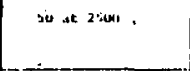 & 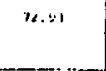 & $\leftrightarrow c 0,0 \times \infty$ & $\because$ & 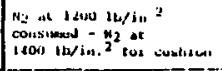 & " & 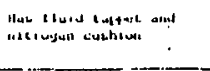 \\
\hline 19 & 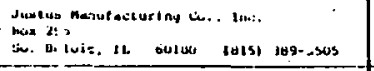 & at 2001 & 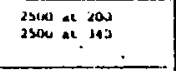 & $\begin{array}{ll}27 \\
65 \\
6\end{array}$ & suitue & ata. and & is & 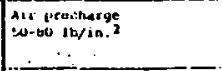 & $\mathrm{s.m}$ & 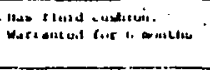 \\
\hline (i) & 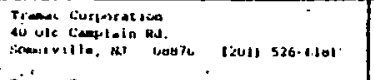 & ane sou & Juan at 625 & $17.24 \times 1600$ & 28.40 & $0.25,000$ & is & $n_{2}$ irrevituryon & 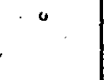 & 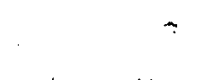 \\
\hline 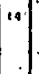 & 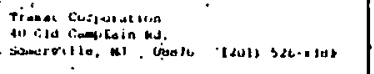 & nitum stwis & $\begin{array}{l}\text { lown }+10: 25 \\
\therefore . .\end{array}$ & $17.44+1000$ & $\because 2.40$ & wes.now & as & ["id waclureryo & - & 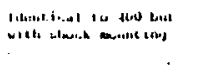 \\
\hline is & 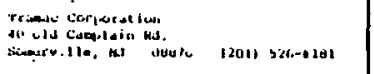 & stat bous & law at as & zo at 1 tass & 21.24 & sou. wow & $\omega$ & 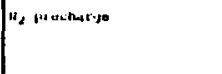 & 0 & \\
\hline 1 & 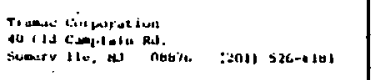 & anil silis & נטג זـ שאהי & 28 a lisu & 11,24 & siv, uav & $\infty$ & 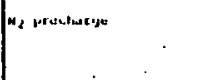 & 。 & 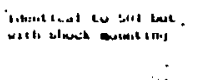 \\
\hline 11 & 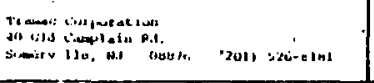 & Dhll sular. & 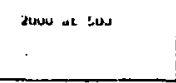 & 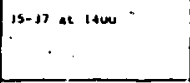 & 10.28 & 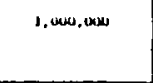 & 100 & 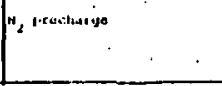 & " & 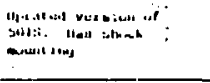 \\
\hline
\end{tabular}




\begin{tabular}{|c|c|c|c|c|c|c|c|c|c|c|c|c|}
\hline & 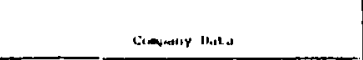 & nukil & 年, & $\begin{array}{c}\text { rrice } \\
\text { ist } \\
\end{array}$ & 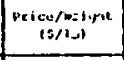 & 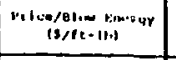 & 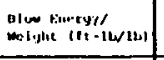 & 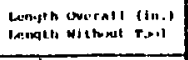 & 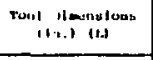 & 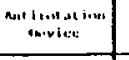 & 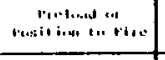 & 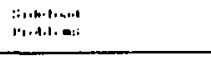 \\
\hline . & 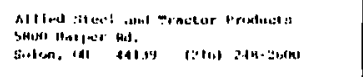 & 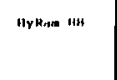 & $\cdots \cdots$ & $3 s, 0100$ & $15.1 \equiv$ & 19.2 & 0.79 & .46 & A in. stumk & 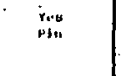 & " & 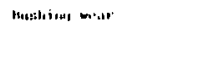 \\
\hline 2 & 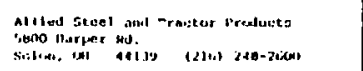 & "Yrk.um "? & 1.tes & $\cdots,(t a m)$ & 11. & 17.0 & 0.07 & Lo vithoun westater & 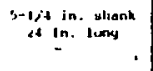 & 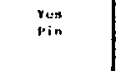 & $"$ & 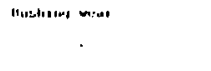 \\
\hline 3 & 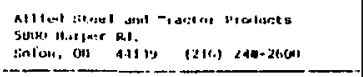 & 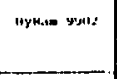 & isus & $\therefore \times, \psi_{0}$ & 11.2 & 18.0 & 0.66 & 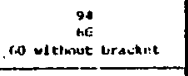 & 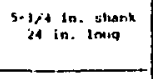 & $\begin{array}{c}\text { raw } \\
\text { rin }\end{array}$ & " & 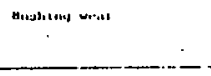 \\
\hline+ & 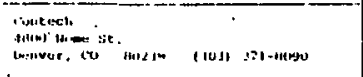 & $m i n-h$ & 1Cम & 10.450 & A. & 4.5 & n. $\times 1$ & $n_{0-1 / 2}^{21}$ & 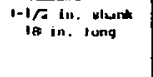 & 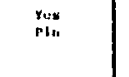 & 2asi. & 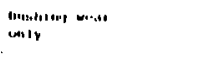 \\
\hline 5 & 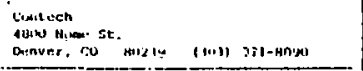 & "10.-10 & 17e". & 21,000 & 12.0r & 4.1 & 1.12 & $\begin{array}{c}90 \\
n-1.22\end{array}$ & $\begin{array}{l}\text { if in. straik } \\
\text { in. Inoyy }\end{array}$ & 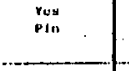 & man. & minting miat \\
\hline " & 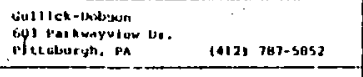 & (a) $\sin 10$ & $n / a$ & $n / 0$ & $n /$. & $i n / a$ & $n / 4$ & $n$ & $1-1 / 2$ tn. shank & iki. & 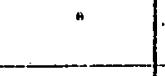 & (Bnkm \\
\hline 1 & 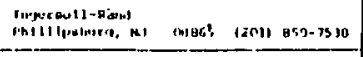 & chlous & I100. & 15,020 & 34.4 & 11.2 & 1.09 & ${ }_{\substack{30 \\
72 \\
\text { bo viture prates }}}$ & 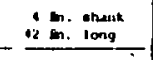 & 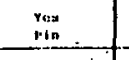 & $"$ & Intur..." \\
\hline 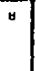 & 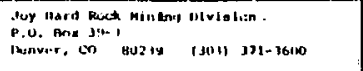 & 2001 & . & $10.0 \mathrm{ki}$ & $20.5^{-5}$ & "1" & 2.86 & is. & $2.1 / 2 \mathrm{In}$. athenk & tor & mastus & 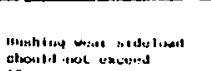 \\
\hline$\cdot$ & 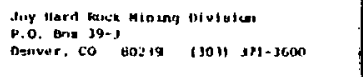 & an & 1600 & 26,1000 & 16. 2 . & 0.5 & 2.90 & $\begin{array}{l}65 \\
34-1,2\end{array}$ & $4.1 / 1$ ta. whank & m & $4 \times 10$ & 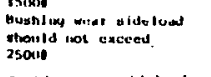 \\
\hline 10 & 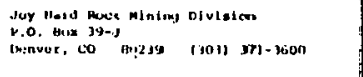 & "1! & lonete & $\| / 4$ & $1 / 0^{-}$ & $11 / 4$ & 3.75 & $\frac{05}{59 \cdot 1,2}$ & $4-1 / 2$ in. shant & no & incour & 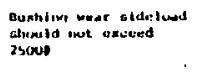 \\
\hline " & 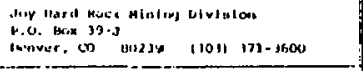 & 514 & $2+4$ & $n$, woro & .16.24 & 2.0 & 9.13 & $\begin{array}{l}86 \\
69\end{array}$ & S.n. Whanite & w.: & minater & 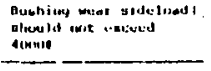 \\
\hline 12 & 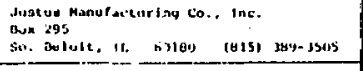 & Nut 2001 & H*. & $13 . \% 35$ & 10.15 & s.n & 2.07 & $\begin{array}{l}78 \\
62\end{array}$ & 1.1/4 in. shank & 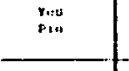 & $=i_{s, s}^{A} 0$ & 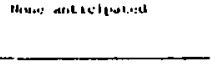 \\
\hline 1) & 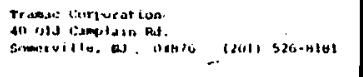 & urat 4nn & 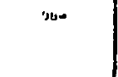 & 15.150 & 16.01 & 15.8 & 1.02 & 67) & 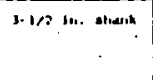 & res & wemer & 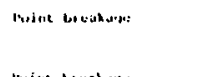 \\
\hline .4 & 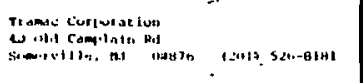 & HRII tinls & w. & $18, y, 0$ & 10.09 & 19.0 & 0.74 & $\begin{array}{l}80 \\
66\end{array}$ & $3-1 / 2$ ln. Wituluk & $\begin{array}{l}\text { res } \\
\text { rin }\end{array}$ & 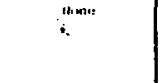 & Mimen renatacto \\
\hline is & 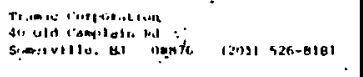 & nat1 4 sit & $\cdots m$ & $21.4 \mathrm{sh}$ & $11.3 n$ & 13.1 & 1..95 & 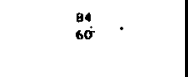 & 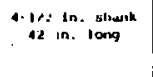 & 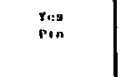 & mome & 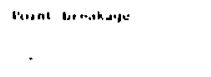 \\
\hline$\cdots$ & 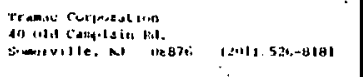 & sont $5.510^{\circ}$ & inerc & 21,450 & $1+.71$ & 19.11 & 0.75 & $\frac{96}{12}$. & $\begin{array}{l}1-1 / 2 \text { in. shatk } \\
42 \text { in. Iong }\end{array}$ & 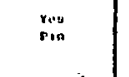 & moxis & Pusul Ireachonge \\
\hline$\because$ & 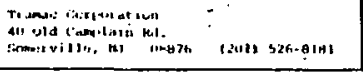 & not snits: & - & $\because .190$ & 11.22 & 10.6 & 0.41 & 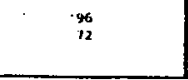 & 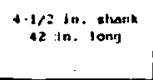 & ing & nune & borme Inedatayu \\
\hline
\end{tabular}


TAELE 2. - Data sheet Joy 4 lia HEFTI data

Hamer Specifications

1. Blow energy:

2. Blow rate:

3. Size:

4. Weight :
$4000 \mathrm{ft} / \mathrm{lb} / \mathrm{blow}$

Varies with oil supply, for example,

$45 \mathrm{blows} / \mathrm{min}$ with $50 \mathrm{gal} / \mathrm{min}$ or

25 blows/min with $25 \mathrm{gal} / \mathrm{min}$

65 in. long and 13 in. 2

a. hammer only - $1600 \mathrm{lb}$

b. nontilt mounting - 1000 lb.

c. $30 \mathrm{deg}$ tilt mounting - $1400^{\circ}$ lb

Bydraulic Requirements

1. Oil supply:

$2500 \mathrm{lb} / \mathrm{in}^{2}$ in range of 25 to $90 \mathrm{gal} / \mathrm{min}$

2. Oil type:

standard petroleum base hydraulic oil

3. Valve:

"On/off" hydraulic control valve with lever or foot pedal within operator's reach (valve preferably open to tank off position)

4. Hose:

For example, with $50 \mathrm{gal} / \mathrm{min}$, one $1 \mathrm{in}$. diam supply hose and one $1-1 / 2$ in. diam return hose are required

5. Filtration:

$10 \mathrm{y}$

6. Boom:

Preferably able to operate boom and hammer simultaneously

Nitrogen R.equirements

The following are to be muluted on the vehicle:

1. Bottle:

2. Control panel:

3. Hosęs :
Linde ' $S$ ' size bottle of commercial grade nitrogen of $130 \mathrm{ft}^{3}$ capacity at $2200 \mathrm{lb} / \mathrm{in} .^{2}-7-3 / 8$ in. diam by 51 in. long

Near operator consisting of valves and gauges with space envelope of $10 \times 12 \times \dot{1 n}$. deep....

To connect above to hammer. Requires two hoses $3 / 8$ in! diam, $2500 \mathrm{ib} / \mathrm{in.}{ }^{2}$

Boom Reguirements

1. Lift capacity:

$3000^{\circ}$ ib with tilt mount

2. "Down pressure":

Not to exceed $8000 \mathrm{lb}$

3. Side load on tool bit:

Not to exceed $25001 b$ 
The sequence of operation

Blow-by-blow operation of the hammer

$$
\text { in }
$$

Rapidexpansion of hydraulically compressed hitrogengas provides the energy for the HEFTI hammers high energy blow. The Fluid Tappet (pressurized fiquid) transmits the piston energy directly to the tool. There is no metat-10 metal impact The four diagrams below stiow the unique impact cycle of the hammer:

and

Hydraulic fluid (fred) introduced through the sleeve valve forces the piston back (fig 1) compressing nitrogen in the annular accumulator (yellow) As the piston passes the main accumulator ports. remaining $g$ as is bypassed from the cylinder into the accumulator (lig. 2). The piston is in cocked position when the sleeve valye is actuated to allow the hydraulic fluid to llow in to the exhaust chamber.. The and a pistón is forced down (fig. 3 ) by trapped gas but the initial gas flow is relatively stow because of the limited bypass This permits full opening of the sleeve value early in the stroke and minimizés back pressute as the thuid is torced into the low prossure exhaust chamber.

$$
\text { ing }
$$

When the sleve value is fully open and gas accumulator ports are cleared by the piston, the unimpeded pressure of the gastrapidiy accelerates the piston (fig 4) to impaci on a trapped volume of nydraulic fluid-the Fluld Tappetwhich drives the striking bar forward if the bit encounters no resistance $e .9$. the rock breaks; a gas cushion arrests striking barmotion:
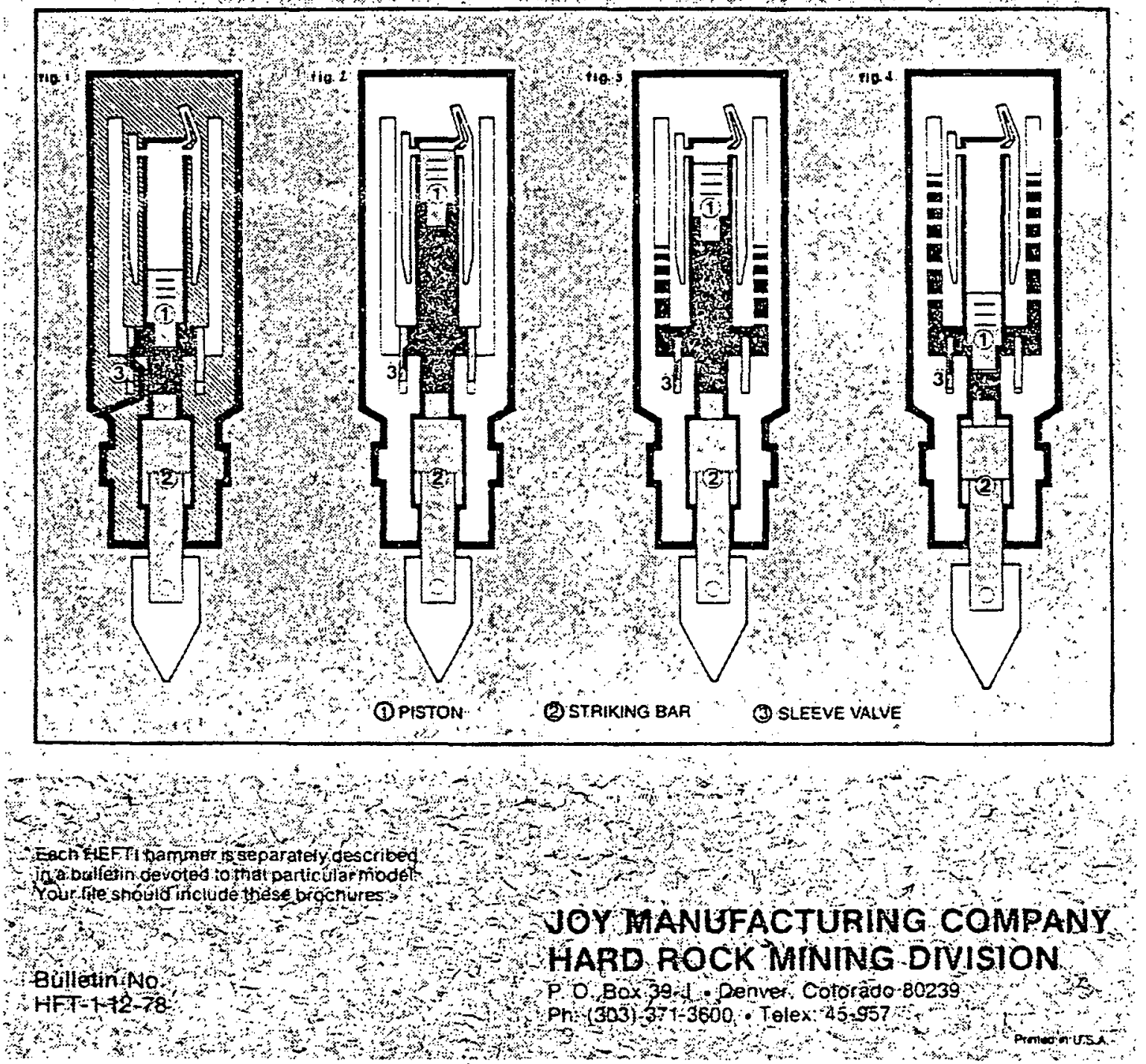

FIGURE 1. - JOY HEFTI operating principle. 


\section{the Nutcracker*}

by CONTECH

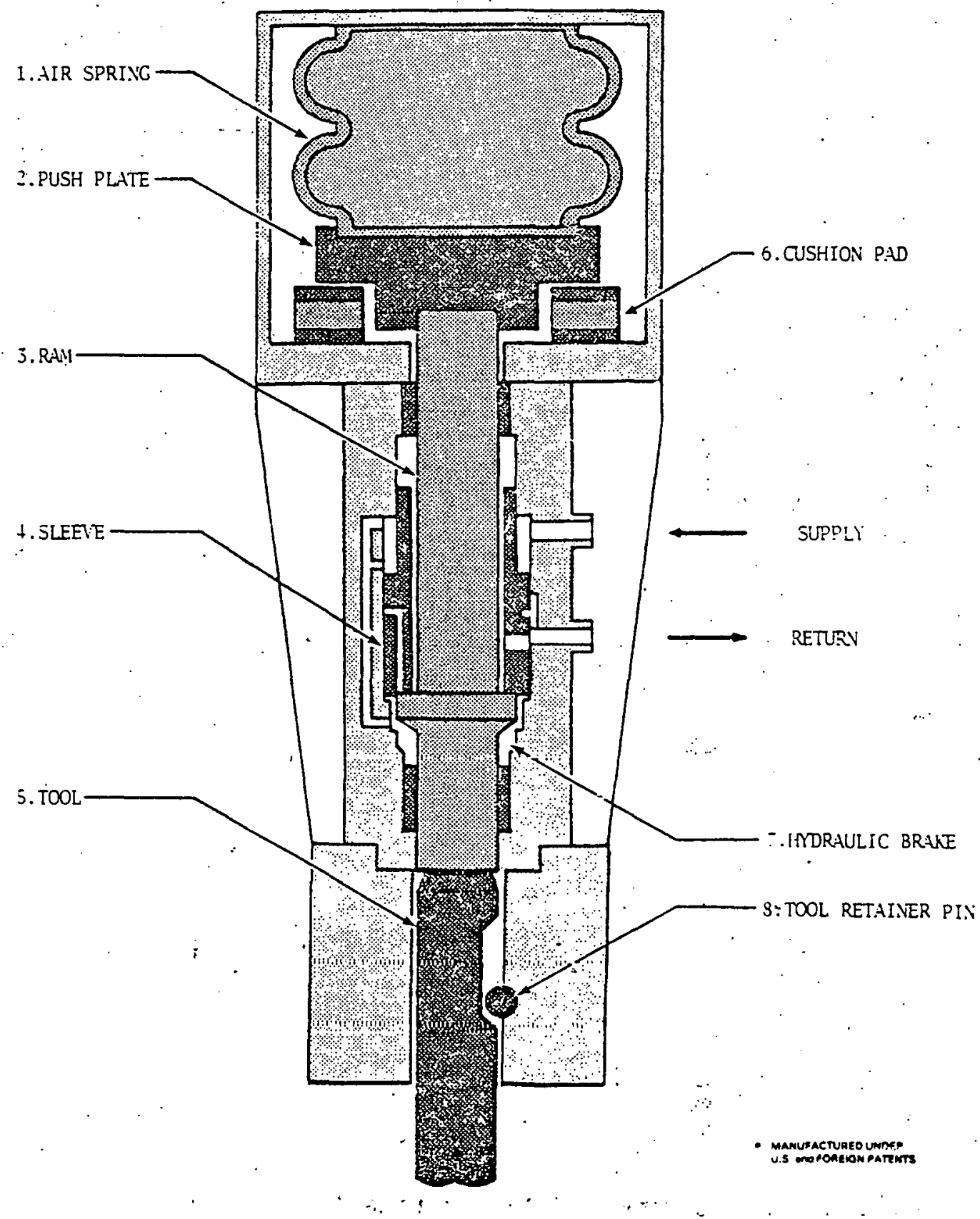

FIGURE 2. - Contech nutcracker operating principle. 


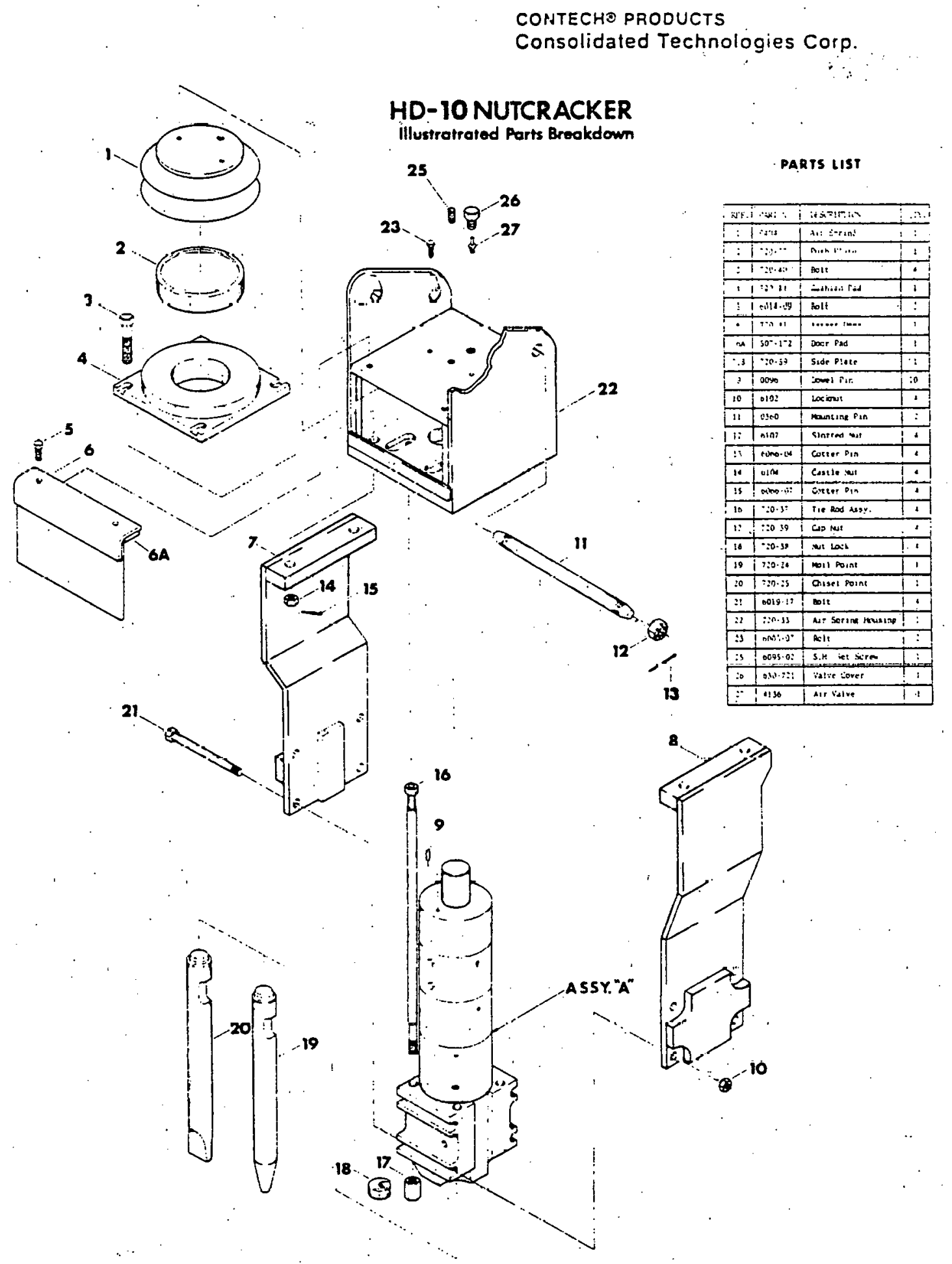

FIGURE 3. - Contech HD-10 parts breakdown. 


$$
\begin{aligned}
& \text { e. Ease of tureability } \\
& \text { f. Simplicity of field service } \\
& \text { g. Energy requirements } \\
& \text { h. Price. } \\
& \text { i. Manufacturer cooperation } \\
& \text { j. Availability. }
\end{aligned}
$$

Contech scored high on all points; especially blow energy, ease of tuneability and manufacturer cooperation.

The Contech HD-10 is easily detuned by reducing the pressure in the air spring, and has a rated blow energy of $2300 \mathrm{ft}-\mathrm{lb}$ at $350 \mathrm{blows} / \mathrm{min}$. It weighs $1740 \mathrm{lb}$ and is $73-1 / 2 \mathrm{in}$. long (without the tool) as compared to $16001 \mathrm{~b}$ (without mounting hardware) and 59-1/2 in. for the Joy 4lla (see Figure 4).

\subsection{Impactors - Principles and Differences in Operation}

The performance of an impact breaker has been reviewed from two widely different perspectives; that of the design engineer interested in improving product reliability and that of the rock mechanician interested in what the tool will do in actual rock fracture.

Because hardrock breakage has been the focus of impactor development, the literature evidences little detail on the general performance capabilities of impactors; particularly performance in a wide variety of materials. In spite of this limitation, there is technical background that is extremely useful for setting the perspective for this program.

In service, an impactor should deliver the highest blow energy possible since experiments have proven that increasing blow energy decreases the specific energy of rock fracture. The primary limitation to improving impactor performance has been decreased structural reliability of the hammer components as the blow energy level, was increased. Until hydraulic cushinn hammers were developed, performance had reached a technological limit because increased blow energy also increased stresses on the impactor.: 


$$
18
$$


With the recent fluid tappet (hydraulic cushion) approach, reliability and performance have been greatly enhanced. Stress levels on the hardware are markedly reduced, while the impulse delivered for rock fracture is essentially unchanged at the same blow energy level (Figure 5).

The difference in impulse is due to a fluid cushion between the piston and the tool. Because there is a cushion, the time over which the kinetic energy is delivered is increased. "This reduces the stress levels in the impacting members in the impactors, and permits higher piston velocities. Because of this feature, fluid tappet impactors can be built with higher blow energy capability than conventional impactors.

The difference in impulse duration is also important in assessing rock response. We know that rock strength properties are dependent on strain rate and that the difference in forcetime loading rates will produce differences in strain rate. We do not know which type of impactor will be best suited to a particular rock formaticn, but we do expect differences in the fractures produced by the two different types of impactors.

\subsection{Hammer Calibration}

During the single hammer test it is necessary for the two hammers to produce the same blow energy to obtain a fair comparison. While it is not absolutely required that blow energy be known quantitatively, it is desirable and a repeatable method of measuring comparative blow energy should be used if at all possible.

The most satisfactory method of hammer calibration is the so-called "Brinell Test" using a drop-weight as a control. This method uses a hardened ball to produce impressions in a steel plate when impacted by a drop weight at various blow energy values. Using a similar hardened ball on the end of its tool, each hammer produces steady state impressions in the steel plate at various gas spring pressures. By comparing impression sizes a correlation is thus obtained between gas spring pressure and blow energy for each hammer. By adjusting the weights of the drop weight and the impacted element, and the impact velocity, a fairly close simulation of Contech HD-10 hammer may be obtained. However, due to the lightweight/high velocity design (that is, the fluid tappet) of the Joy 4 IIA the correlation for this hammer should be considered as only comparative.

A less expensive method of:comparison for the single hammer test would be to eliminate the drop weight calibration and to compare the impression size of the contech HD-10 at maximum 

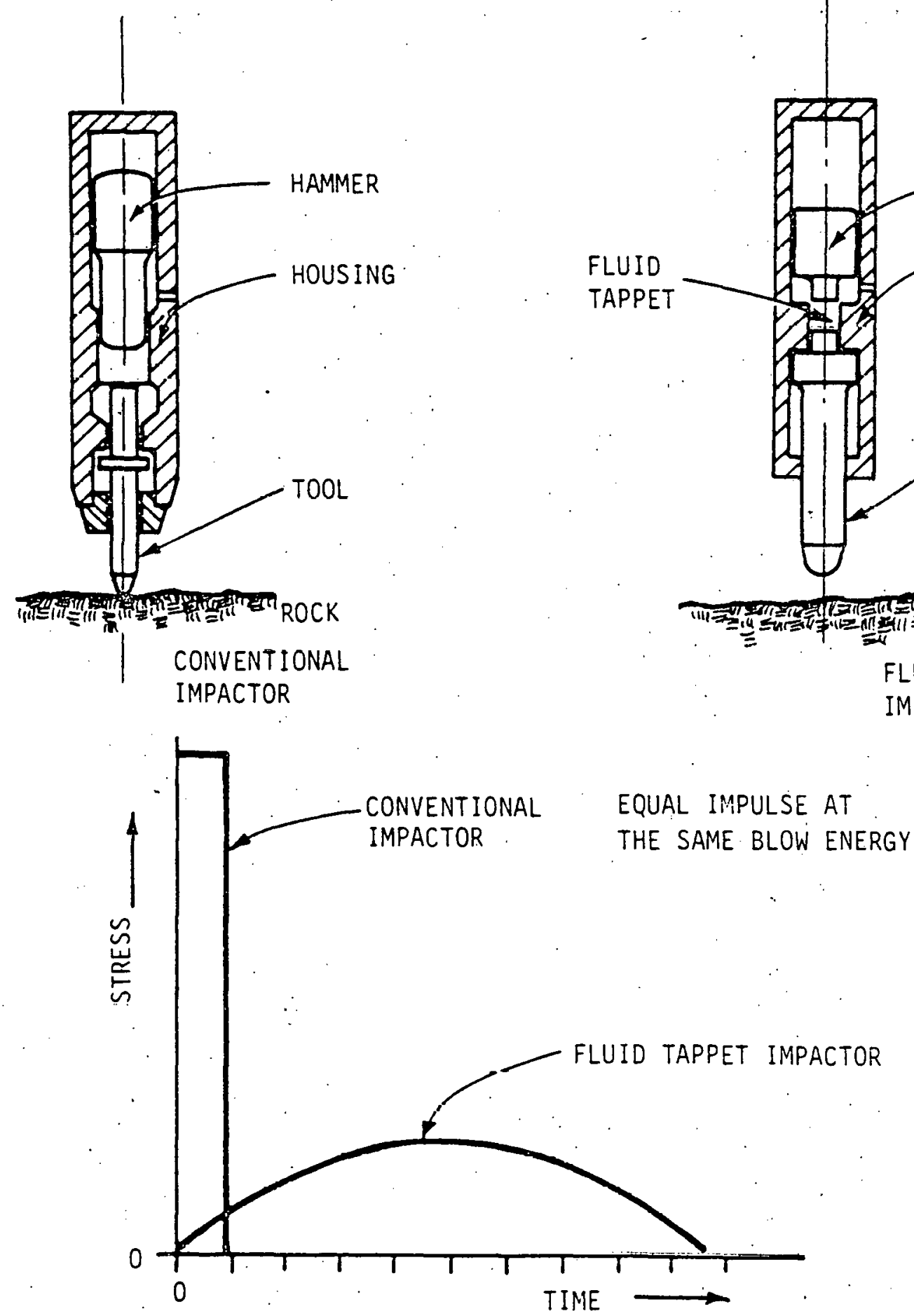

FIGURE 5. - Equal impulse at the same blow energy. 
blow energy with impressions made by the Joy 4 Ilis, detuned in increments until the impression sizes were the same. At this point it might be assumed that the two hammers are delivering the same blow energy to the plate. Unfortunately, even these "less expensive" tests are not inexpensive, and this contract did not envision or intend to devote significant resources to measuring blow erergy or to verifying manufacturer's. blow energy ciaims, even though some of them are known to be greatly inflated.

After examining the methods used by Joy and Contech to determine blow energy, FMA believes. that variations between claimed and actual energies are likely to be small, hopefully much smaller than the difference between "soft" and "hard" biows (fluid tappet versus conventional). Consequently, we will utilize the following procedure: The Joy $411 \mathrm{~A}$ hammer will be detuned to 2300 ft-lb blow energy using a Joy supplied calibration curve. The rated maximum output of the contech HD-10 hammer $(2300 \mathrm{ft}-\mathrm{lb})$. is the value at which the single hammer comparisons will be run. 


\section{TASK 3 - DESIGN PROTOTYPE IMPACTOR ARFAY TEST SYSTEM}

The Rapidex/FMA SAM Trolley (shown in Figure 6) has been modified to carry the hammer array. Due to the weight and recoil loads of the three hammers the basic structure has. been strengthened as follows (see Figure 7):

- The lower structure has been fitted with longer longitudinal beams of greater cross section which increase the length of the wheel base. The wheel base width has also been effectively increased and has been fitted with fuur crane wheels and bearinge to support the increased loading.

- The upper structure has been stiffened by adding additional members. The horizontal support frame for the SAM cutter has been removed and has been replaced by a vertical "door" structure on which the hammers are mounted.

Depth of cut is controlled by the lateral position of the sliding upper structure relative to the wheeled lower structure. This position is adjustable in $3 \mathrm{in.} \mathrm{increments.} \mathrm{The} \mathrm{"angle}$ of attack" of the cutter head(s) is adjustable by means of retaining the "door" at various angles to the direction of travel.

The hammers are mounted on independent support structures which are bolted to the door. By changing the relative vertical positioning of these structures array spacing can be varied. Provision has been made to mount the two types of hanulis with-' out changing any other parameters. Progression along the face is maintained by haulage of the vehicle along the rail track. This haulage is accomplished by means of a winch turned by a hydraulic motor. Hydraulic power for the hammers and the winch

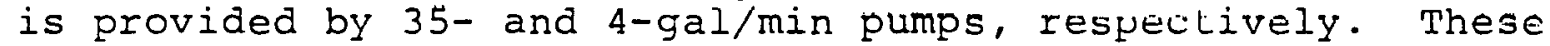
pumps are driven by the 40-hp diesel engine already existing on the SAM vehicle. Drawings SK-01 and SK-02 (Figures 8 and 9) show the modified SAM vehicle looking in the direction of travel and from the coal face (with the door and hammers removed) respectively. Drawings SK-03, SK-04 and SK-05 (Figures 10 to 12) show details of mounting arrangements of the Joy $4 I I \mathrm{~A}$ and Contech HD-10 hammers. Drawing SK-06 (Figure I3) shows the various clearances available at different angles of attack, and the proposed hydraulic system is indicated in Figure 14. 

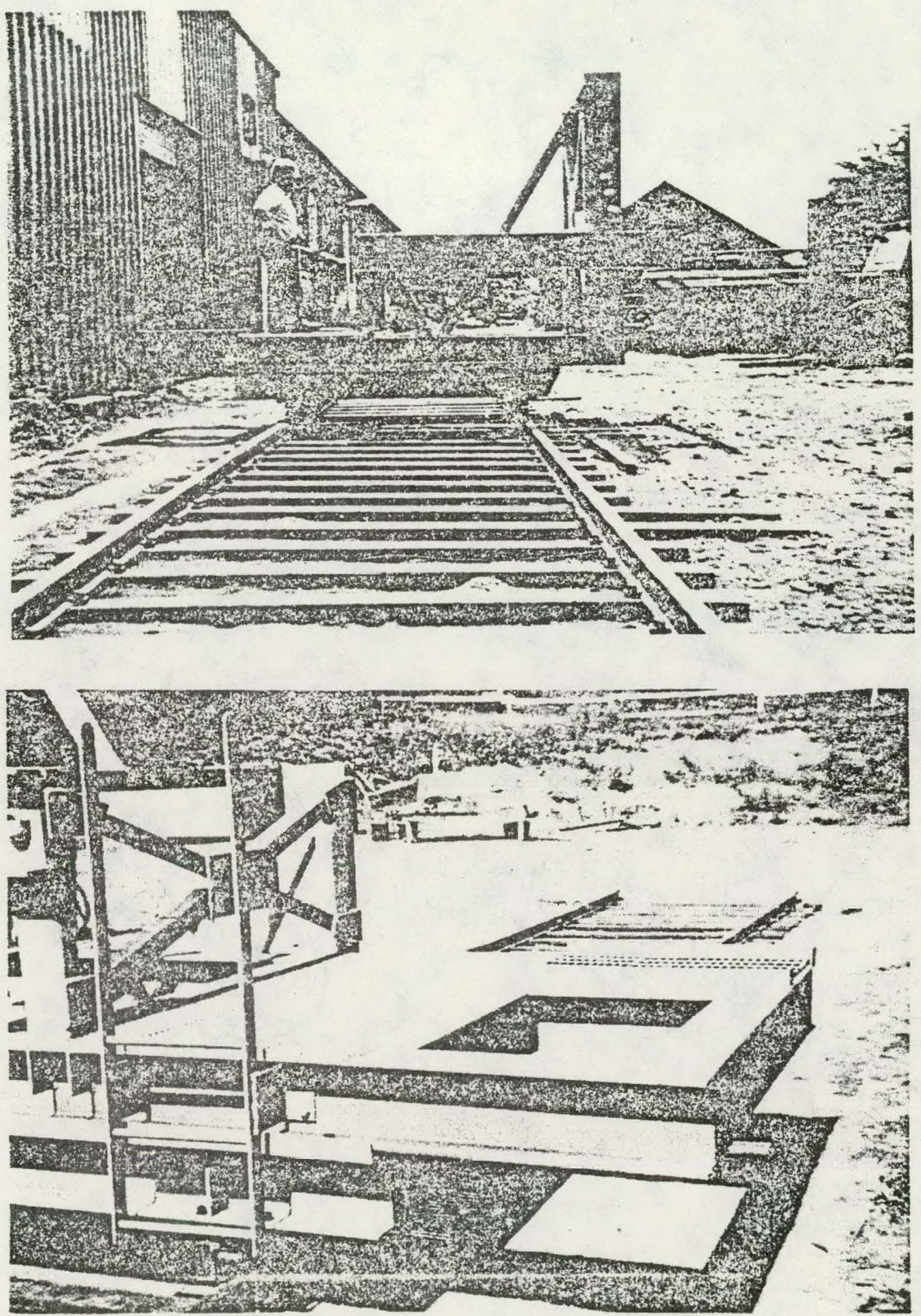

FIGURE 6. - SAM test vehicle. 


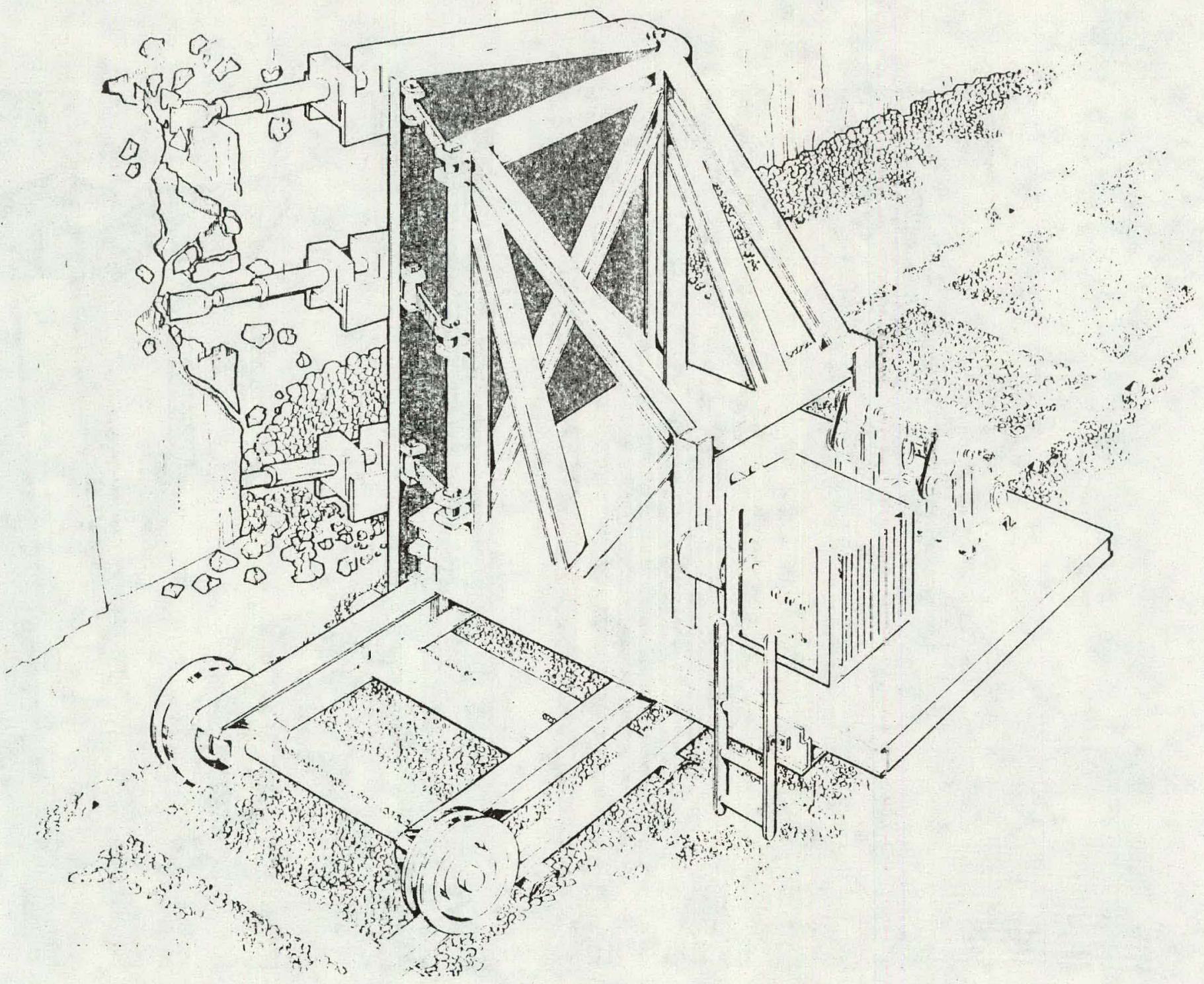

FIGURE 7. - Impact hammer array test vehicle. 


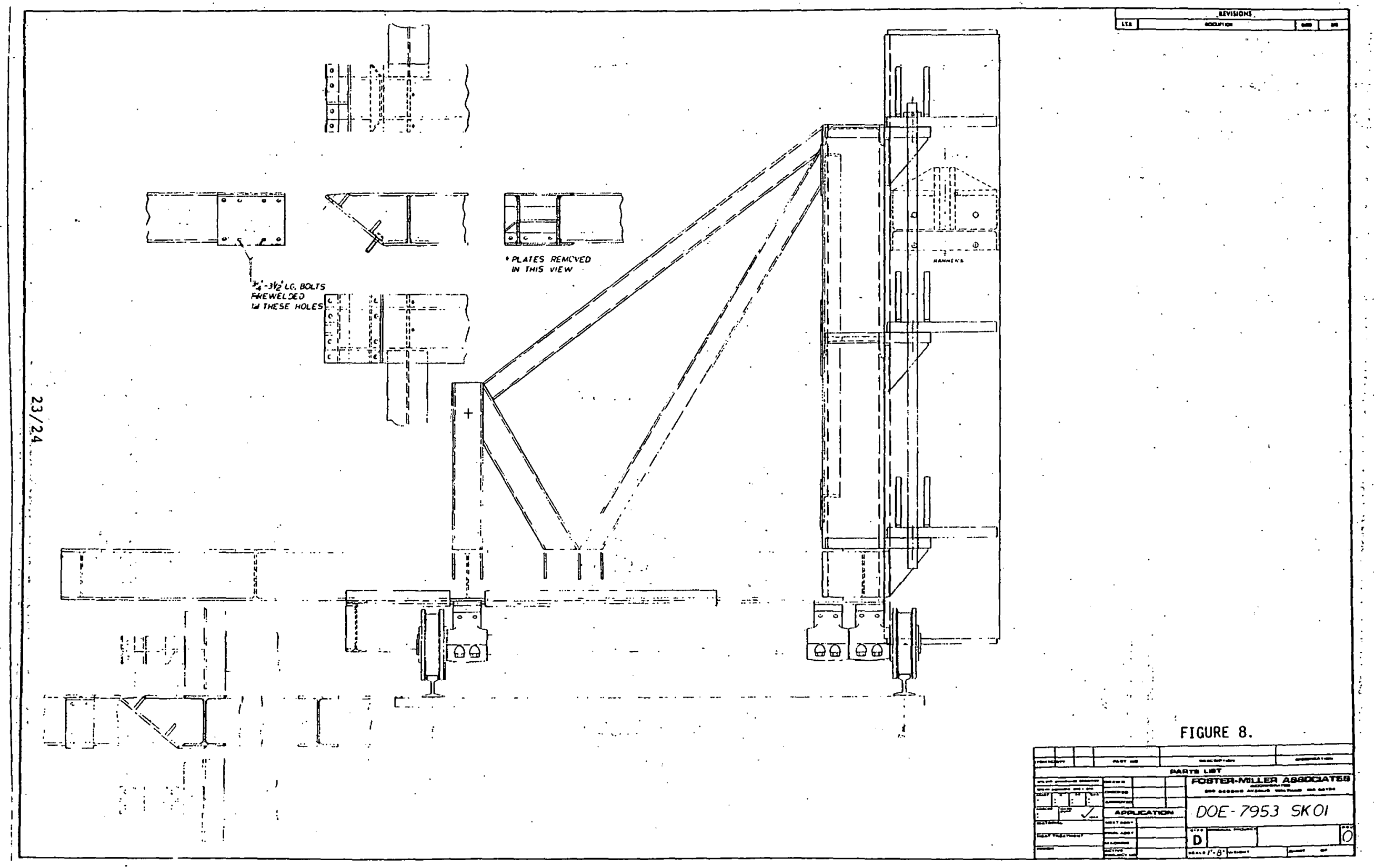




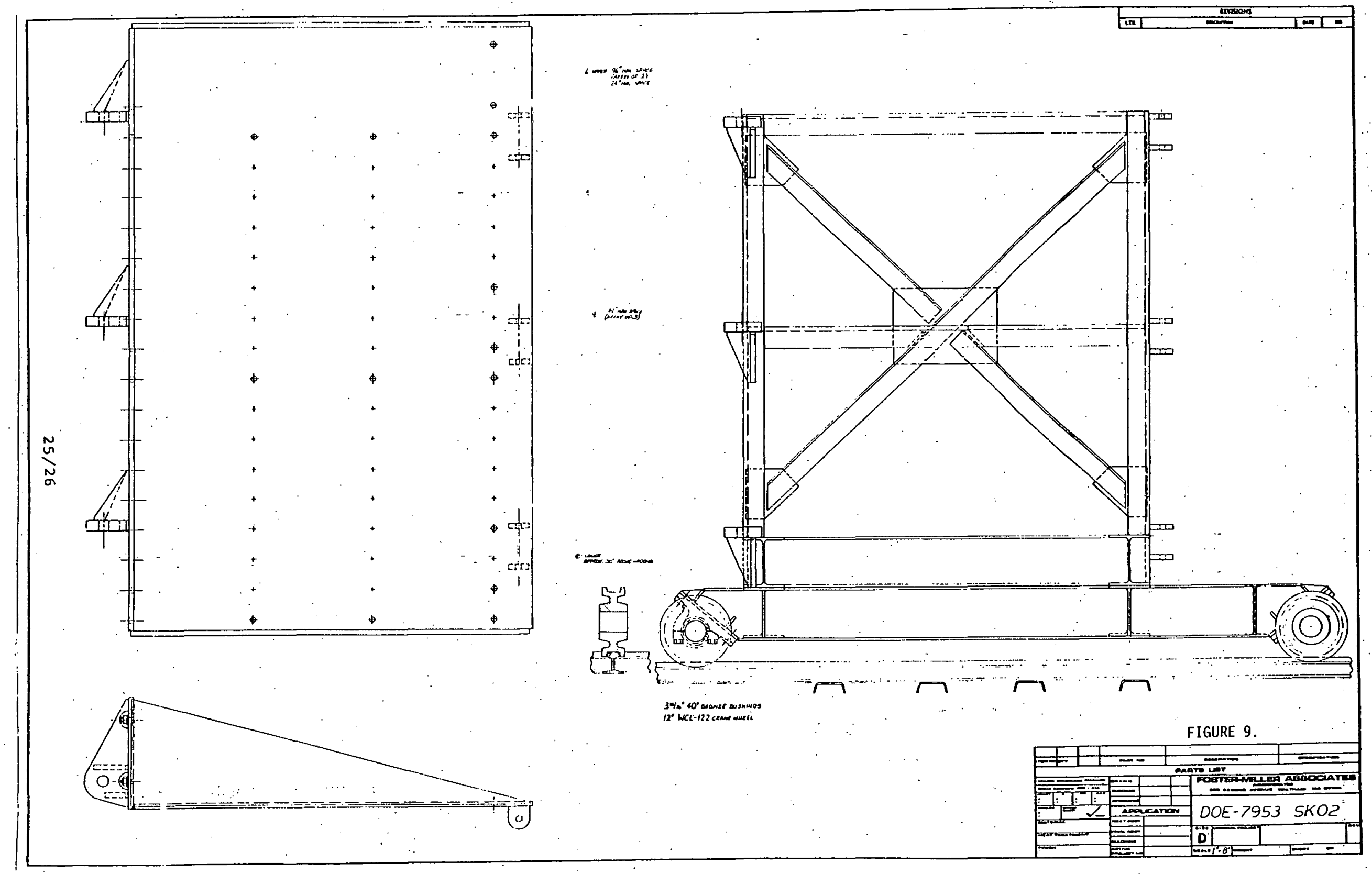




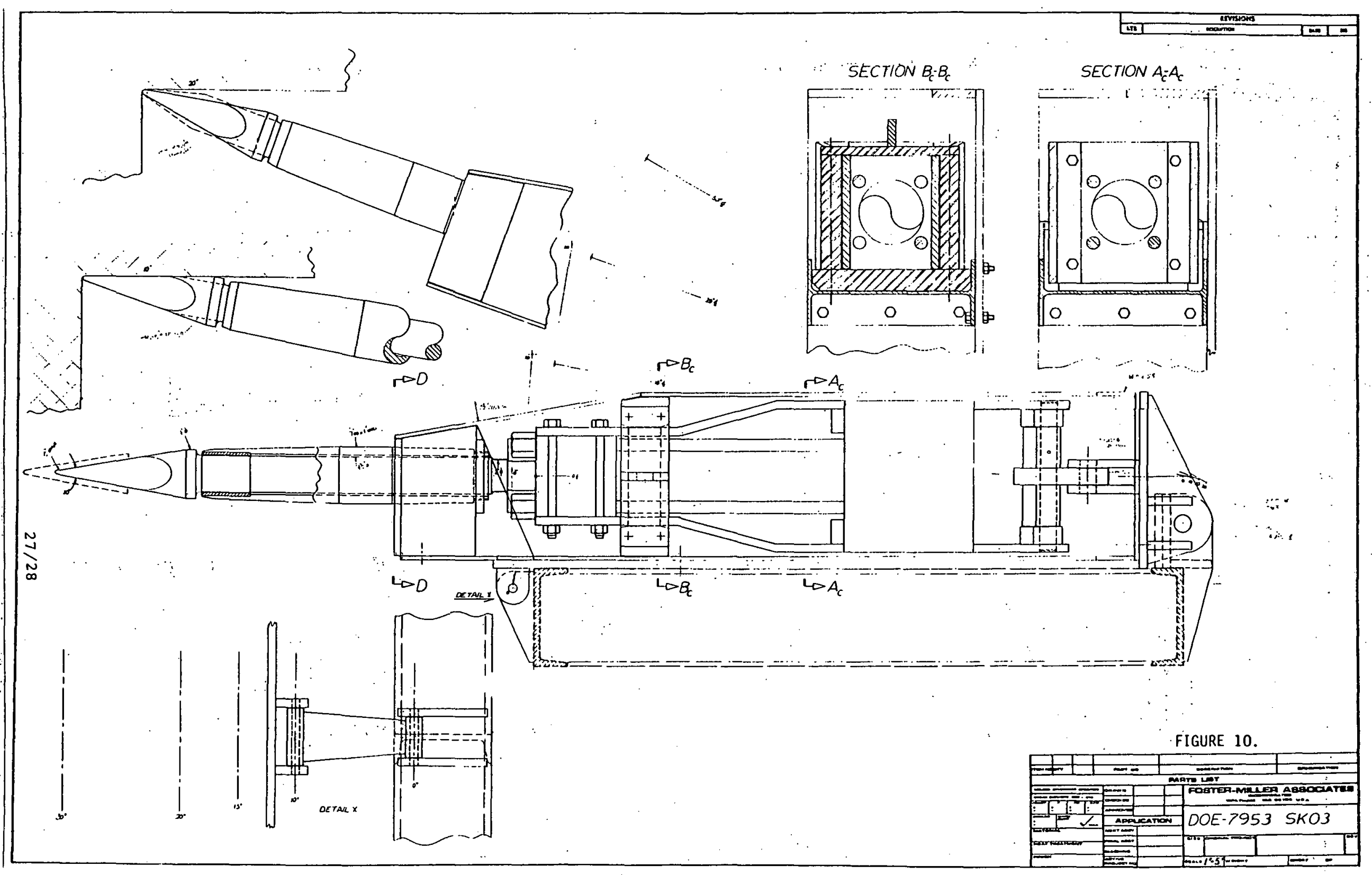




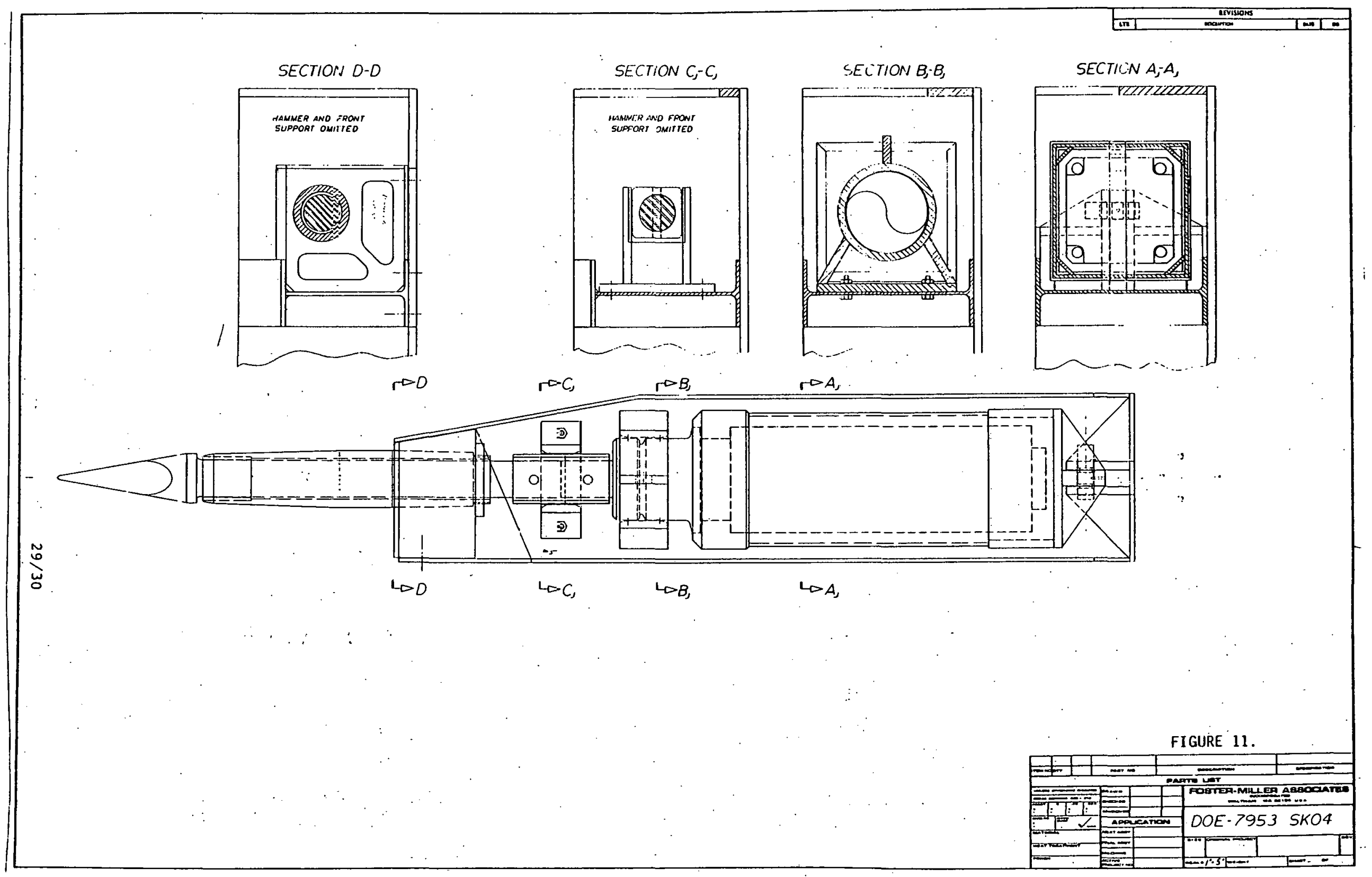




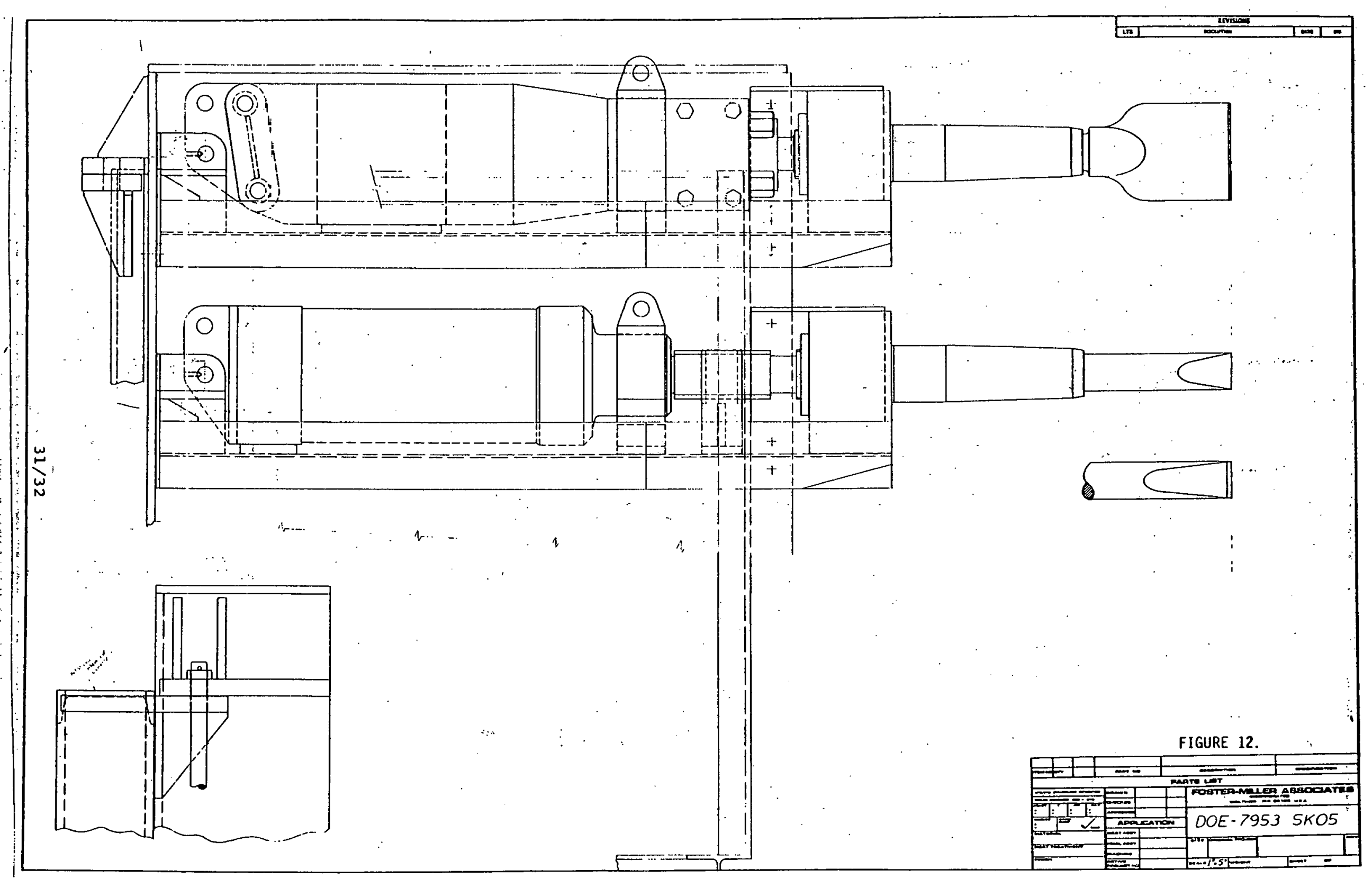




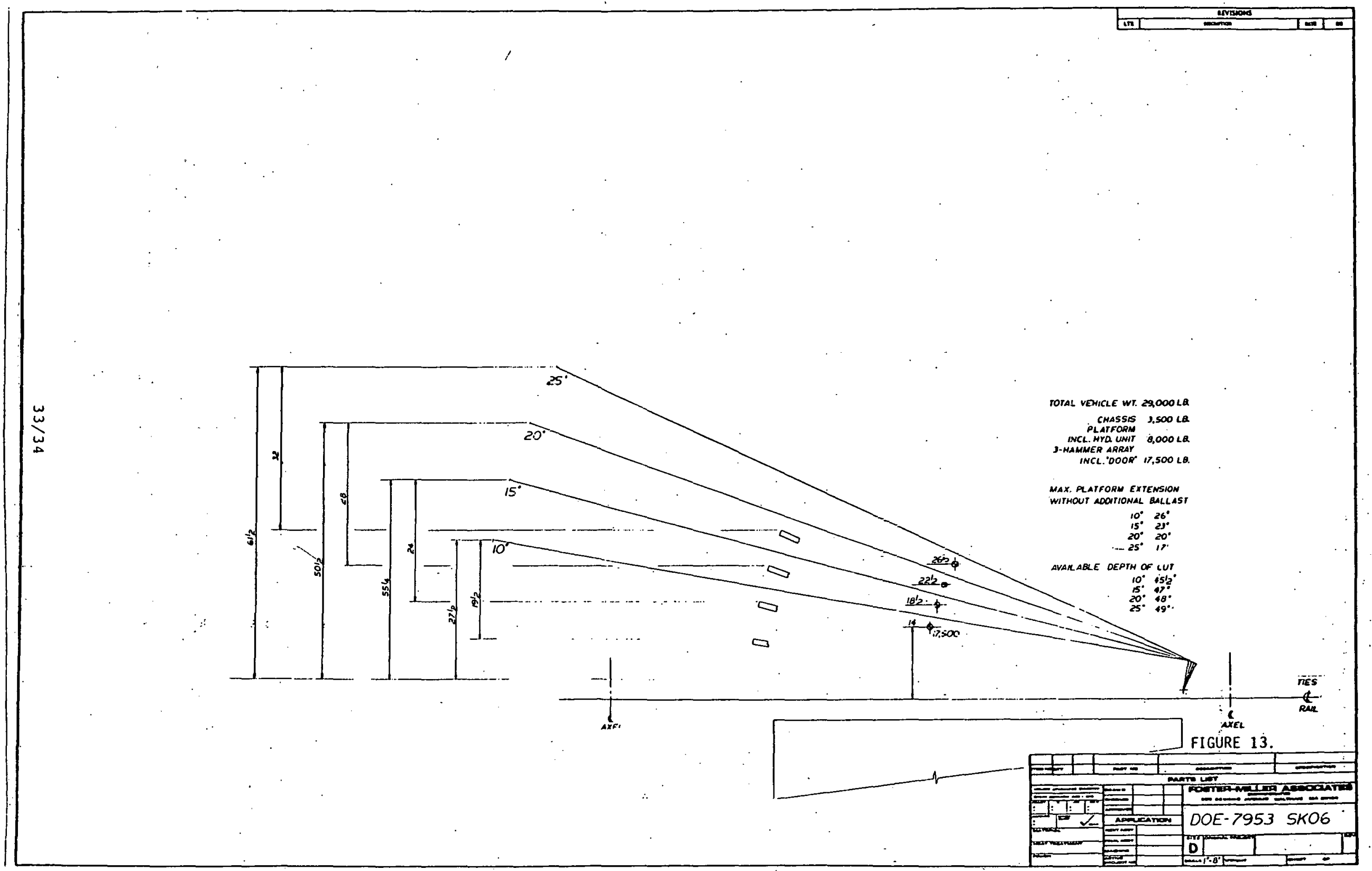




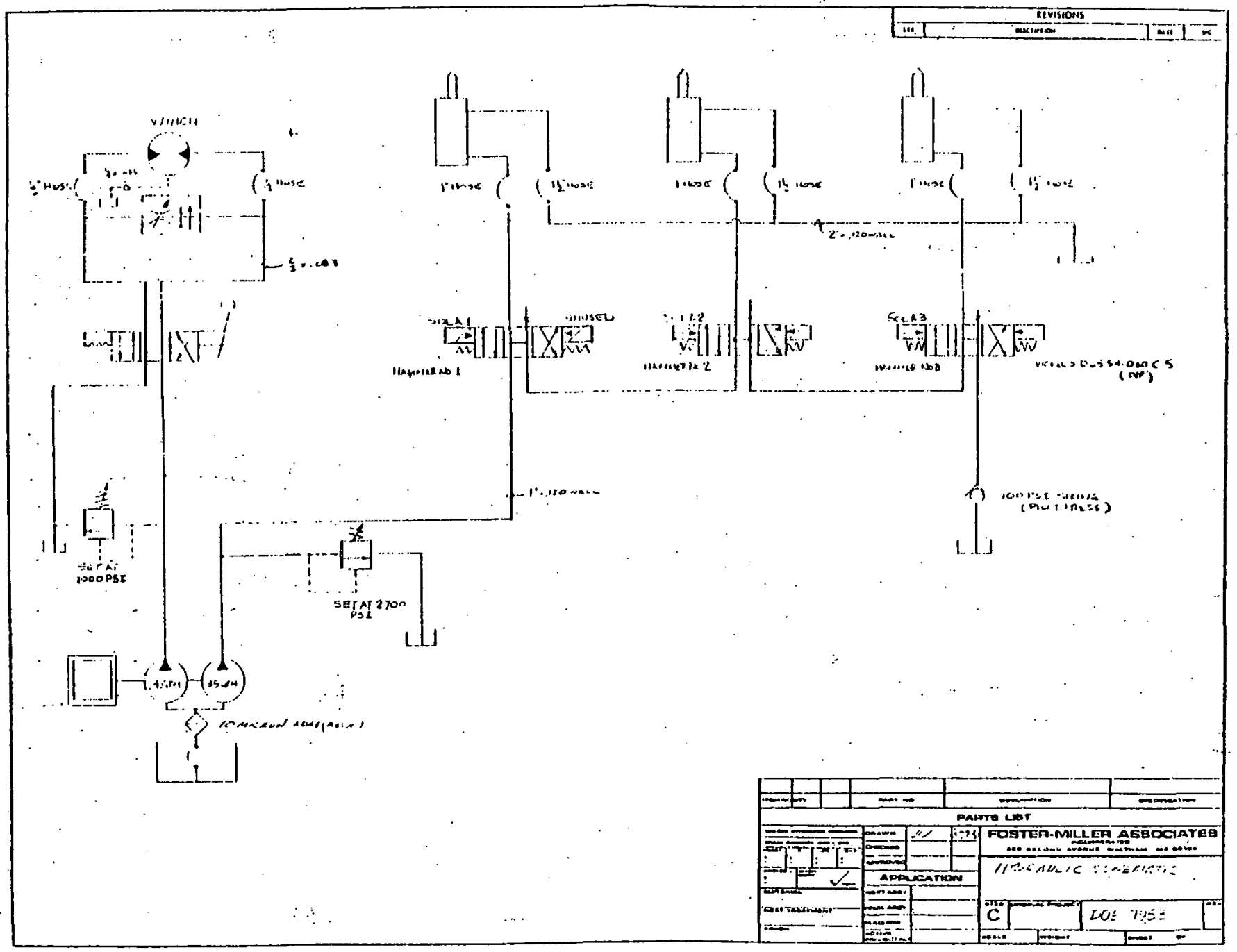

FIGURE 14. - Iydraulic schematic. 


\section{TASK 4 - PREPARE PARAMETRIC TEST PLAN}

\subsection{Test Objectives}

The objective to these tests is to determine the feasibility of developing a continuous surface mining machine utilizing impact breakers to excavate coal and overburden without recourse to blasting. The test vehicle, which is not a mining machine, is designed to investigate the relationships between the mechanical and geologic variables in a parametric study, and to define optimum configurations for a possible continuous surface mining machine.

\subsection{Test Plan Summary}

The test plan is divided into four parts; two types of coal and two types of overburden representing the extremes of range of geologic conditions found in western surface mines. Each part is subdivided into two sections; single hammer tests and three hammer array tests. The total number of tests in the matrix is expected to be 129. The complete test plan matrix is included in the appendices.

\subsection{Field Eguipment}

A Melroe "Bobcat 310" (Figure 15) front end loader will be used to clear the working area of muck for removal to the weighing.site. The Bobcat has a 35 in. wide bucket, rated at 500 lb operating capacity.

A portable, digital readout weigh scale, capable of weighing the Bobcat and its load, will be used to record the quantity of rock or coal removed during each test run.

- A Stanley SK-58 portable hydraulic rotary/percussive sinker drill. (Figure 16) will be used to drill for the rail bolts. Hydraulic power will be available on the test vehicle. A speedaire air compressor $17.6 \mathrm{FM}$, 100 lb/in. ${ }^{2}$ ) will be used to provide drill hole clearance.

- A trailer of 4000 lb capacity will be used for on-site storage of test equipment. Since four test sites are to be used the trailer is mobile (wheeled) to facilitate the moving. 


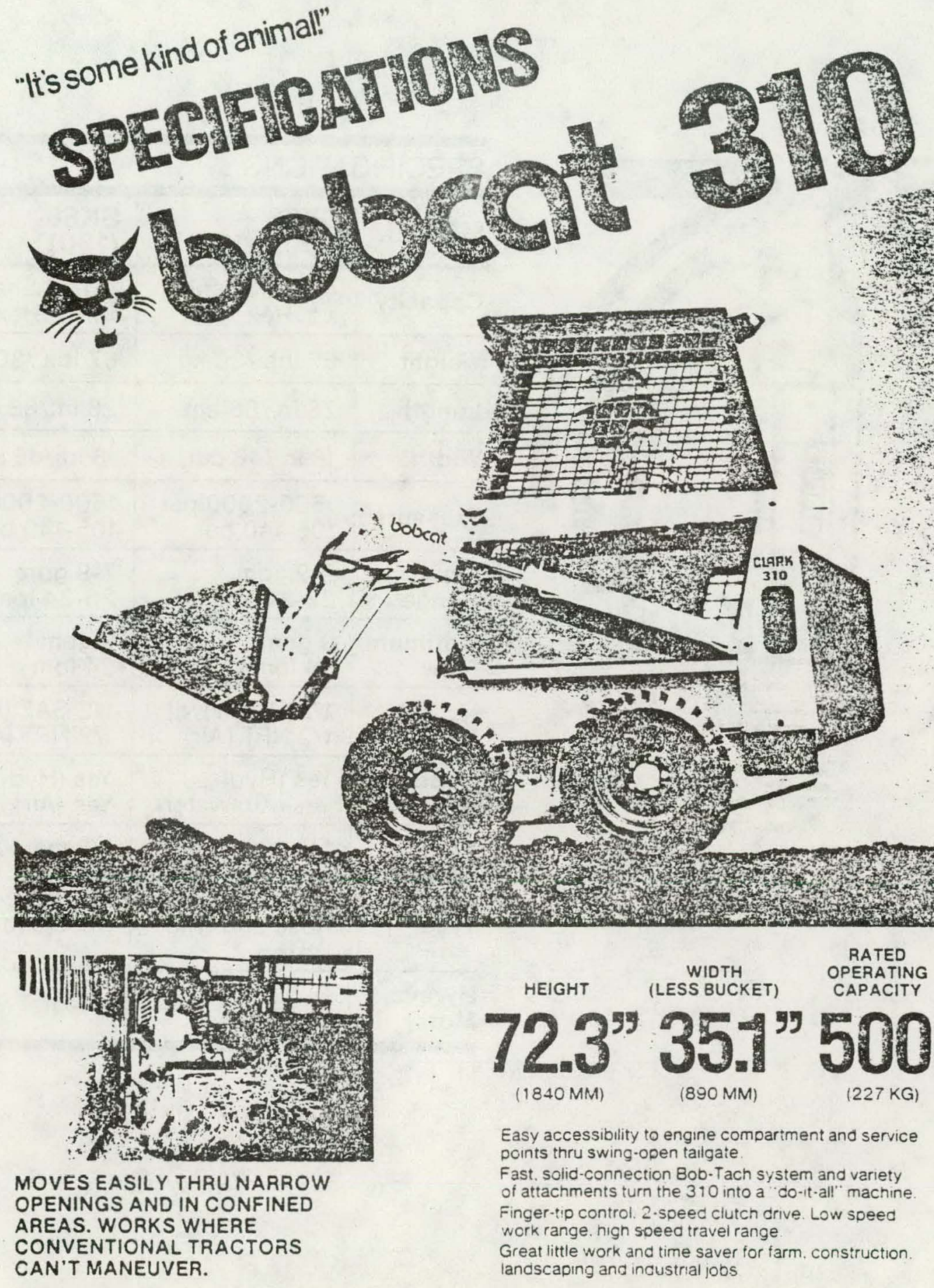

\section{CLARY}

MELROE DIVISION

CLARK EQUIPMENT COMPANY -

FARGO. ND 58102

FIGURE 15. - Bobcat 310. 


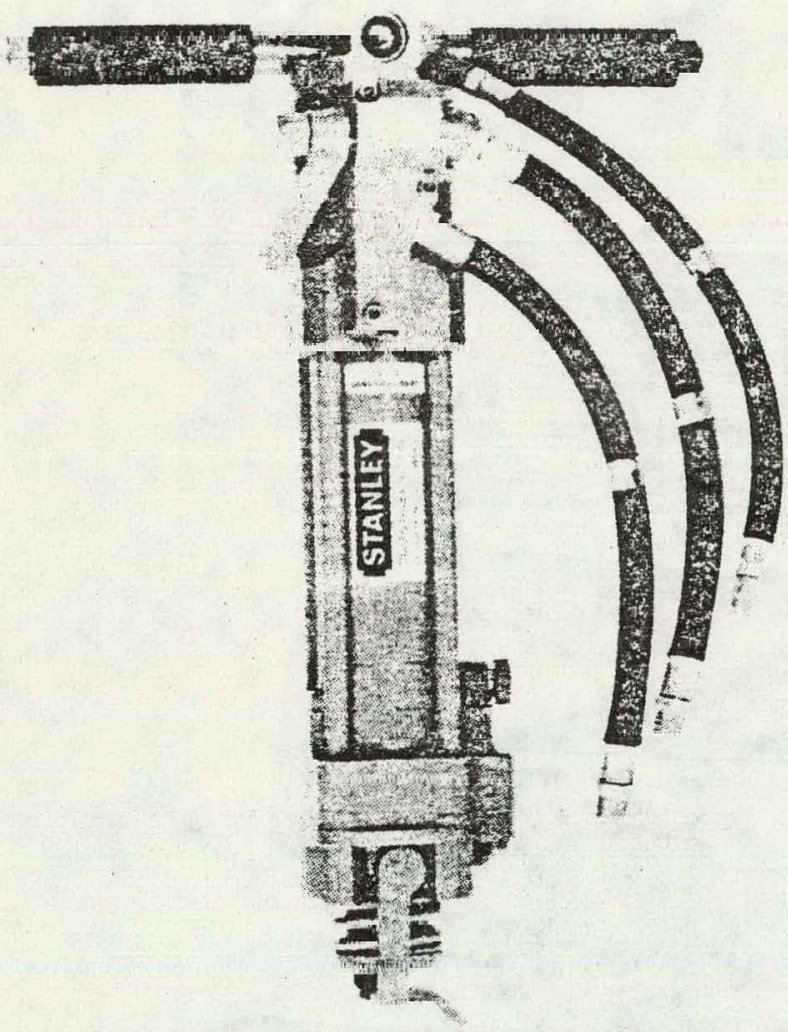

\begin{tabular}{|c|c|c|}
\hline MODEL & $\begin{array}{l}\text { SK58 } \\
(110 \& 120)\end{array}$ & $\begin{array}{l}\text { SK58 } \\
(130)\end{array}$ \\
\hline Capacity & $\begin{array}{l}4-1 / 4^{\prime \prime} \text { Shank } \\
\times 1{ }^{\prime \prime} \text { Hex }\end{array}$ & $\begin{array}{l}\text { 4-1/4" Shank } \\
\times 7 / 8^{\prime \prime} \text { Hex }\end{array}$ \\
\hline Weight & 67 lbs. $/ 30 \mathrm{~kg}$. & $67 \mathrm{lbs} . / 30 \mathrm{~kg}$. \\
\hline Length & $26 \mathrm{in} . / 66 \mathrm{~cm}$. & 26 in. $/ 66 \mathrm{~cm}$. \\
\hline Width & $18 \mathrm{in} . / 46 \mathrm{~cm}$ & 18 in. $/ 46 \mathrm{~cm}$ \\
\hline Pressure & $\begin{array}{l}1500-2000 \mathrm{psi} \\
105-140 \mathrm{bar}\end{array}$ & $\begin{array}{l}1500-2000 \mathrm{psi} \\
105-140 \mathrm{bar} \\
\end{array}$ \\
\hline $\begin{array}{l}\text { Flow } \\
\text { Range } \\
\end{array}$ & $\begin{array}{l}\text { 7-9 gpm } \\
26-34 \mathrm{Ipm}\end{array}$ & $\begin{array}{l}\text { 7-9 gpm } \\
26-34 \mathrm{Ipm}\end{array}$ \\
\hline $\begin{array}{l}\text { Optimum } \\
\text { Flow } \\
\end{array}$ & $\begin{array}{l}9 \mathrm{gpm} \\
34 \mathrm{Inm}\end{array}$ & $\begin{array}{l}9 \mathrm{gpm} \\
34 \mathrm{lpm} \\
\end{array}$ \\
\hline Porting & $\begin{array}{l}\text { 1/2 SAE (Hyd) } \\
1 / 2 \text { NPT (Air) } \\
\end{array}$ & $\begin{array}{l}1 / 2 \text { SAE (Hyd) } \\
1 / 2 \text { NPT (Air) } \\
\end{array}$ \\
\hline $\begin{array}{l}\text { Hose } \\
\text { Whips } \\
\end{array}$ & $\begin{array}{l}\text { Yes (Hyd) } \\
\text { Yes (Air/Water) }\end{array}$ & $\begin{array}{l}\text { Yes (Hyd) } \\
\text { Yes (Air) }\end{array}$ \\
\hline $\begin{array}{l}\text { Connect } \\
\text { Size and } \\
\text { Type }\end{array}$ & $\begin{array}{l}1 / 2 \text { male pipe } \\
\text { hose end (Hyd) } \\
3 / 8 \text { male pipe } \\
\text { hose end (Air/ } \\
\text { Water) }\end{array}$ & $\begin{array}{l}1 / 2 \text { male pipe } \\
\text { hose end (Hyd) } \\
3 / 8 \text { male pipe } \\
\text { hose end (Air) }\end{array}$ \\
\hline $\begin{array}{l}\text { Hyrevz } \\
\text { Motor }\end{array}$ & Integral & integral \\
\hline
\end{tabular}

FIGURE 16. - Stanley SK-58 sinker drill. 
A 3750W Grainger combination generator/weider will be used to power lighting for night-time testing, and welding equipment for possible on-site repairs.

A portable electric grinder will be used to maintain tool edges.

\section{4 Instrumentation}

Longitudinal jorces will be measured by a 50,000 lb STRAINSERT in the mounting of each hammer. The device will measure the longitudinal forces, will be used to initiate the firing sequence when the force exceeds the chosen preload, and will acknowledge firing by indicating the recoil spike.

Side loads on tool will be measured by a strain gauge on the tool guide. The gauge will be calibrated to indicate bending strains as point loads at the tool tip.

Firing Selector - The cocking of the three hammers will be on an "as required" basis, initiated by the longitudinal force exceeding the preload, as measured by the STRAINSERT. After the cocking cycle, the hammer will automatically fire and the recoil spike will initiate closure of the valve. The selector will wait for the next hammer to reach the preload value. If a hammer has already exceeded preload it will immediately go into the cocking sequence. If more than one hammer has already exceeded preload the selector will cock the hammer with the highest loading, since only one hammer is allowed to fire at a:time. (See Figure 17.)

- Blow counter - Recognition of the recoil soike in the firing selector will be used to count the total number of blows during a test run. The signal will be totalized by an electronic counter.

Haulage load - The test plan calls for constant haulage force. In fact, hammer preload will be the constant since actual haulage force could vary from zero to $30,000 \mathrm{lb}$. (three times the hammer preload since it is possible for all three hammers to be preloaded equally). Average haulage force over the length of the run will 


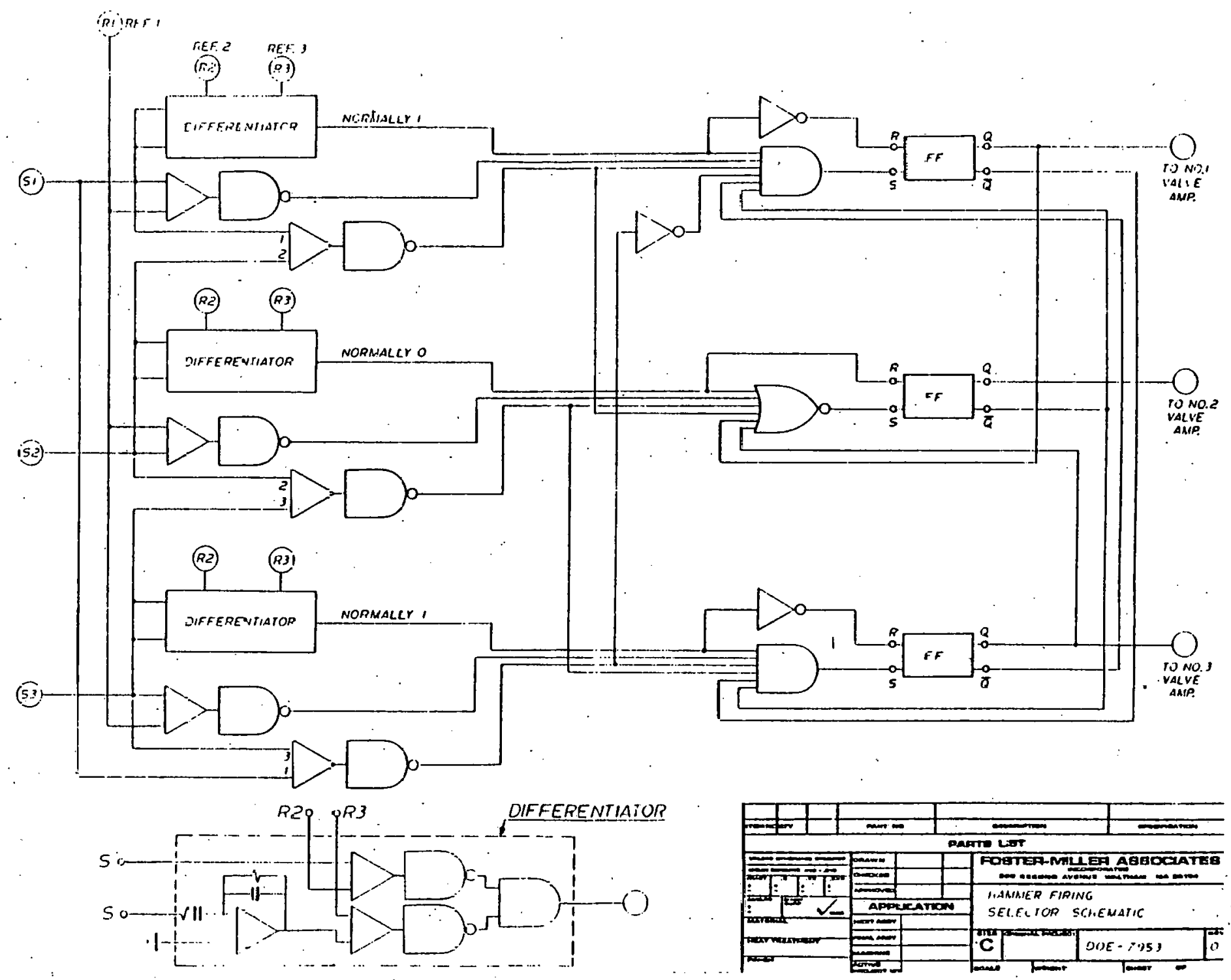

FIGiJRE 17. - Fir 
be recorded using a 50,000 lb. STRAINSERT in the haul line. Continuous integration of haulage load and distance to give total haulage "energy" will be displayed digitally.

- Run time and distance run will be electronically recorded and used to determine average velocity and horsepower.

Eleven channels of data will be recorded on-site on magnetic FM tape. They are:

- Three longitudinal forces (zero to 50,000 1b)

- Three tool side loads (zero to 25,000 lb)

- Haulage force (zero to 50,000 Ib)

- Distance run (zero to $50 \mathrm{ft}$ )

- Time of run (i sec marks)

- Hydraulic oil pressure to array (zero to
3000 lb/in.

- Hydraulic oil flow to array (zero to $50 \mathrm{gal} / \mathrm{min}$ ).

Three additional channels will be available for the possible recording of three vertical tool loads (zero to 25,000 lb). This additional data is not presently required by this contract. on-site data will be gathered by a 14-channel FM tape recorder and manually noted readings. The recorder will be a Honeywell model, that brand having been selected for future compatibility with equipment already in DOE's possession at the Carbondale Research. Facility. 


\section{SUMMARY AND CONCLUSIONS}

Except for definitive results for Task 1 , Phase I of this contract has been completed on schedule and in accordance with the requirements of the contracting document.

Obviously, since the test vehicle is based on the SAM equipment, much of the hardware is already in existence. However, some of the remaining purchases have relatively long lead times and approval for their acquisition should be handed expeditiously.

'l'he basic tindings of this phase are. that industry interest in the concept of impact mining tends toward the removal of multiple thin seams of coal and parting rather than deep coal or overburden and, while the intent of this contract is to explore the feasibility of impactors in a vertical array for use in a terraced mine plan, future design of a continuous mining machine should take industry acceptance into account. 
APPENDIX A

RESPONSE OF ROCK TO IMPACT FRACTURE 
Different coals and rocks exhibit varying degrees of strain rate sensitivity, but all are generally stronger at higher strain rates. Dresser Basalt is perhaps the best known rock in tisis regard, as Figure $A-1$ shows. At room temperature, the compressive strength (unçonfined uniaxial) varies from 55,000 to 85,000 to $110,000 \mathrm{lb} / \mathrm{in} .2$ for strain rates of $0.0002,0.24$, and 1000 sec-l, respectively.

In a very simplified analytical form, Figure A-2 shows this effect of this behavior on excavation energy. The energy to rupture is:

$$
\mathrm{U}=\frac{1}{2} \sigma \varepsilon
$$

Substituting

$$
\begin{aligned}
& E=\sigma / \varepsilon \\
& U=\frac{1}{2} E \varepsilon^{2}
\end{aligned}
$$

If rupture occurs at Point 1 at low strain rate, and Point 2 at a higher strain rate, then the ratio of energy (higher/lower) iss

$$
\frac{U_{H}}{U_{L}}=\frac{\varepsilon_{H^{2}}}{\varepsilon_{L}{ }^{2}}
$$

In other words, as the strain rate goes up, the energy to break goes up with the square of the increase in strength, assuming the modulus $E$ is unchanged.

We do not know if this behavior will be of sufficient magnitude to have an influence in the proposed effort, because the range of strain rates imparted by commercial hammers is not as great as those shown in Figure A-I. Some range does exist, however, and it would appear to favor the fluid tappet hammers. We will see. 


\section{SwRI Projec:: $\quad 02.3092$ \\ Contract: $\quad H 0210036$ \\ Sponsor: $\quad$ U.S. Department of the Interior \\ Bureau of Mines \\ Twin Cities, Minnesota}

Inclusive Dates: $3 / 5 / 71-4 / 4 / 72$

\section{Program Brief}

The objectives of this program were to jetermine the development of dynamic test techniques applicable to testing hard rock under relatively high confining pressures, present the results of an extensive series of tests on Dresser basalt, and correlate the strength data obtained with 3 failure criterion which incorporates both temperature and strain rate. All tests were performed in uniaxial compression or extension with the radial confining pressure varied from 0 to 100,000 psi, strain cates from $10^{-4}$ to $10^{3} \sec ^{-1}$, and temperature from 80 to $300^{\circ} \mathrm{K}$. The testing was accomplished with hydraulic loading facilities at the lower strain rates and with a newly.developed Hopkinson pressure bar apparatus at the highest strain rates. The test results with Dresser basalt shoried a strong dependence of the ultimate or iracture strength. on both temperature and rate of deformation. The combined temperature-rate dependence of the streng:h indicated that the fracture was controlled by a themal activation process. A fracture criterion was formulated in terms of the three principal stresses, the temperature and the applied strain rate. It was sinown that all the experimental data obtained cortelated very well with this fracture criterion. The unconfined compressive strength was found to vary from 41,000 psi to 125,000 psi over the range in temperature and strain rate used in :his study, with the higher strengths obtained at low temperatures and high strain rates.

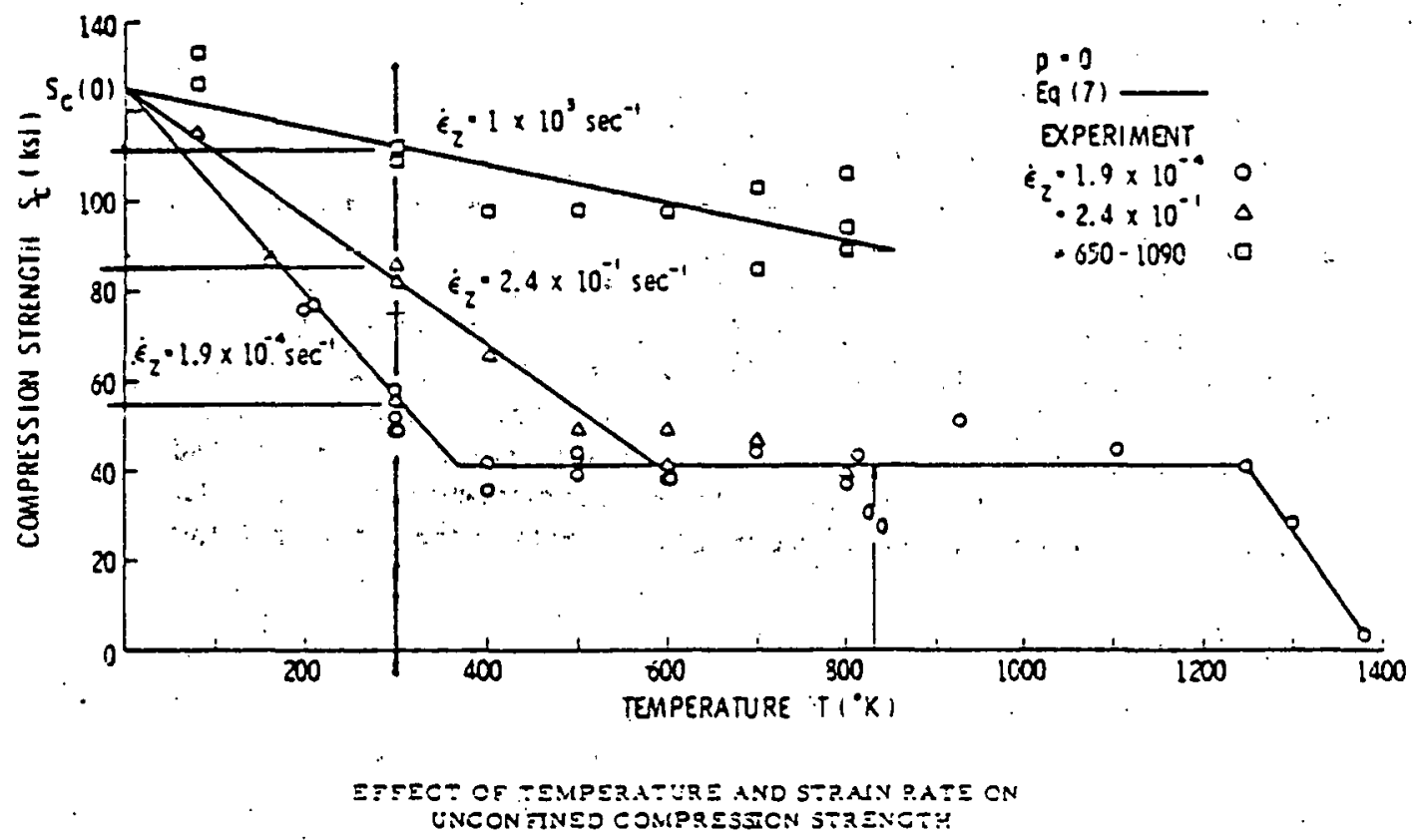

FIGURE A-I. - A study of the dynamic strength and fracture. properties of rock. 


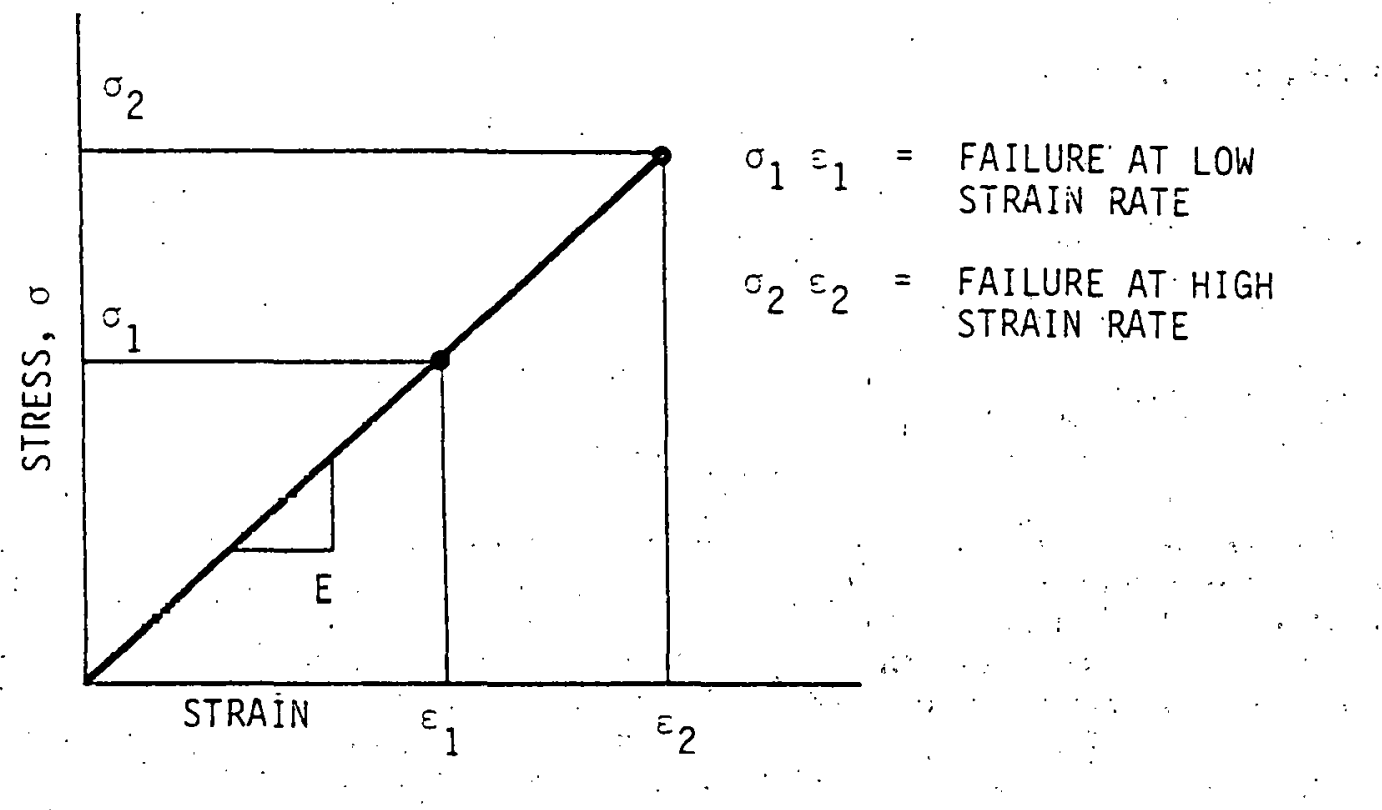

FIGURE A-2. - Relationship of excavation energiy. to strain rate.

of larger importance, we feel, is the blow energy itself. The following excerpt from Evans and Pomeroy* is self-explanatory.

\section{IMPACT BREARAGE}

The forces that act on a tool cutting in coal fuctuate widely (see Fig. 11.2) and the peak forces frequently exceed three times the mean cutting force. On multi-pick machines it is bighly unlikely that all of the picks that are cutting at the same time will have peak forces acting on them simultaneously, so that the shaft or sprocket torque will not vary so much. On the other band, on coal ploughs which have a small number of blades cutting at once the baulage force fluctuates continuously ${ }^{(6)}$. A possible way to reduce the load variation in the haulage chain tiould be to provide ex.lu jower to the blates when and only when peak loads occur. Experiments in the laboratory and

* Strength, Fracture, and Workability of Coal, Pergamon Press, 1966. 


\section{Breakage of Coal by Weage Action-l}

underground bave been undertaken to see if stored eaergy could be used to break the coal by impact when the ploughing forces become large. The experiments were designed to see what size of biow would be aeeded to break the coal and to see whether repeated blows of lower energy at one point would initiate and propagate cracks. Experiments were carried out on a friable South Wales steam coal and ca the strong Barnsley Hards. Grooves were cut in the place surface of coal blocks by a succession of impacts from a simple wedge attacied to the end of a pendulum. The magnitude of the impulse was varied by altering the angle tbrough which the peadulum swung and by varying the mass on the ead of the pendulum. A diagram of the apparatus is shown in Fig. 11.14. A 0.5 in. wide wedge was used to cut. a groove

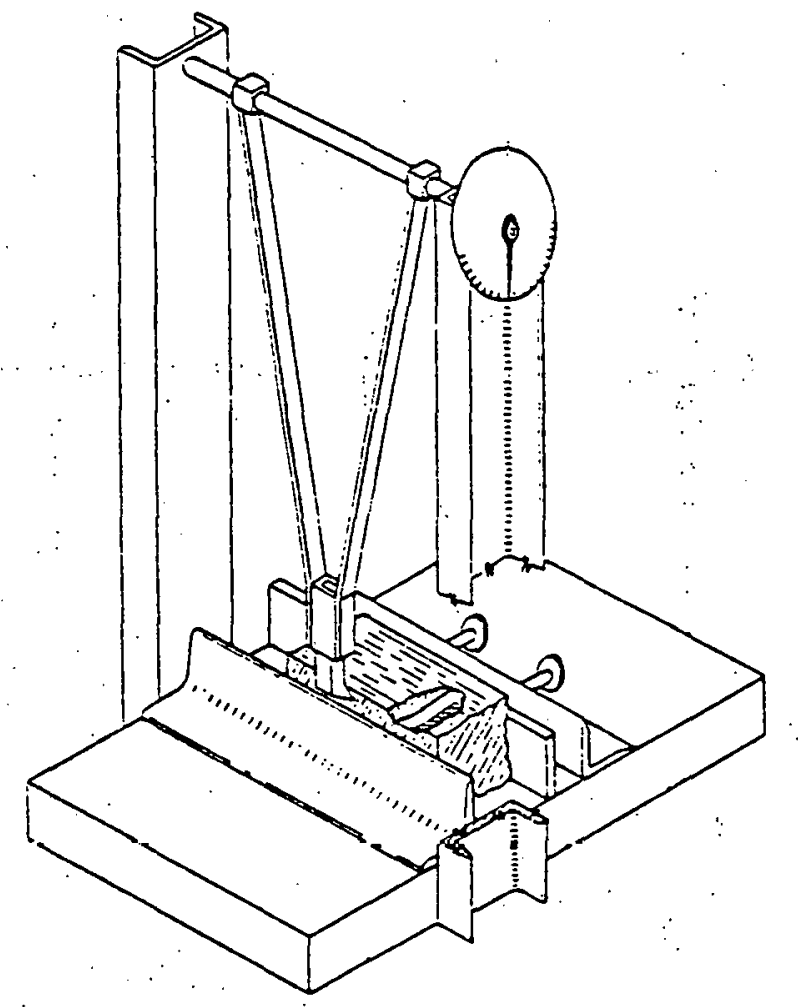

FiG. 11.14. Diagram of apoaratus.

$0.5 \mathrm{in}$. deep in the friable coal and a $0.375 \mathrm{in}$. wide wedge to cut grooves 0.125 in., 0.5 in: and 0.375 in. deep in Barnsley Hards.

The principal findings were:

(i) The erergy required to break coal was at best comparable with the energy used in continuous cutting but for blows that were too light or too heary impact breakage was bighly inefhcient (see Fig. 11.15(a)). 
Strength, Fracture and Workability of Coal

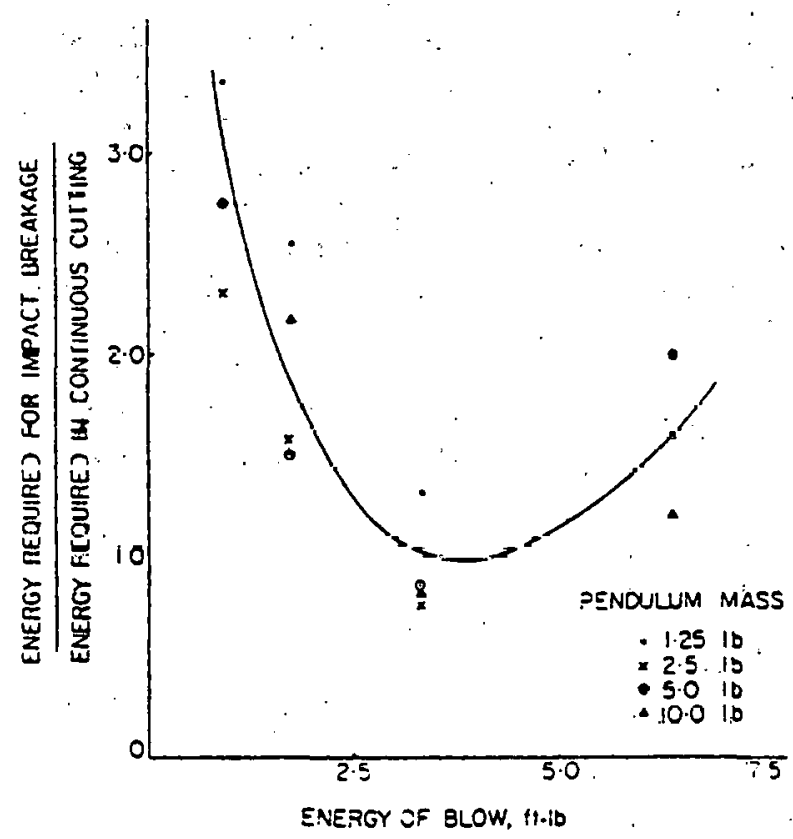

FiG. 11.15(a). The erergy required to cut coal by a suceession of impacts compared with the energy used on continuous cutting for different sizes of blow.

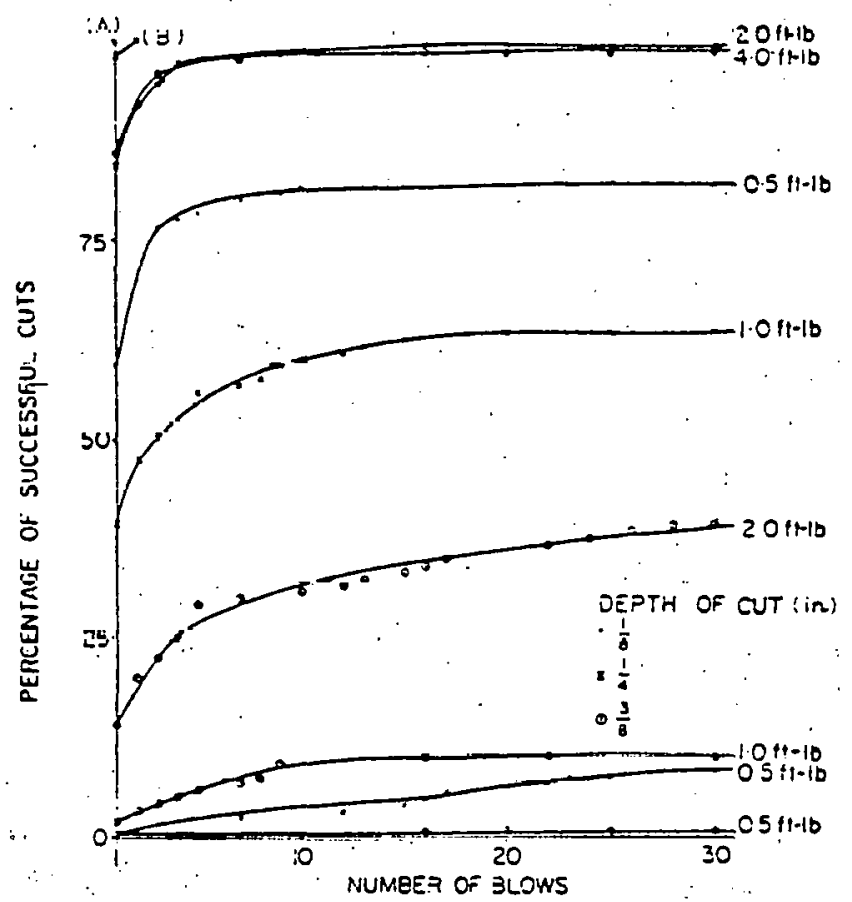

FiG. 11.15(b). The effect of repeased impact on breakage. (A) 1.0.2.0 and $4 \cdot 0 \mathrm{ft} / \mathrm{lb}$ blows, $\frac{1}{8}$ in. deptb of cut: (B) 4.0 fr'th biows, $\frac{1}{4}$ in. depth of cut. 


\section{Breakage of Coal by Wedge Action-1}

(ii) If breakage is not effected by the tirst few blows, repeated impact will not cause breakage no matter how many blows are imparted (Fig. 11.15(b)).

(iii) A blow of at least 3000 ft-lb is needed to break a 6 in. by 6 in. section from Barnsley Hards in the seam. A lower value would be aeeded for weaker coals but these are relatively easily ploughed and so are not likeiy to need help from impact.

It is thought that light blows are ineffective because the firsi impacts form a cushion of fine coal around the tool tip and successive blows are absorbed by this cushion. Unnecessarily large impacts are inefficient since the excess power applied is partly absorbed in the machine and partly in unwanted degradation and dispersion of the coal.

These findings have been confirmed ${ }^{(7)}$ in underground tests on a friable (Cwmtillery, Garw) and a strong (Blackwell B Winning, Three-quarter) coal. Impacts up to $1000 \mathrm{ft}-1 \mathrm{~b}$ were used to cut prepared buttocks of coal to depths of 4 in.; 6 in. and 8 in., with blades 8.5 in. and 12 in. high. It was shown that even $1000 \mathrm{ft}-1 \mathrm{~b}$ blows did act often fracture the buttock of coal at the first attempt, even for the shallowest ctits. It was also shown that if repeated blows were needed to fracture the coal (and it. Was not always possible to do this) the energy required to break a given amount of coal rose rapidly.

As the use of unnecessary eaergy sisults in added degradation of the coal, a system that needs repeated impact iu break the coal cannot be advocated.

Evans and Pomeroy have also found that cracks propagate in coal at a speed of at least $200 \mathrm{ft} / \mathrm{sec}$, * which is faster than the velocity of any impact hammer piston. Since the crack will cease propagation as soon as the stress is removed, it would follow that the crack will propagate farther for a given blow energy if the stress (the hammer blow) is applied for a longer duration, assuming, of course, that a minimum threshold stress is achieved. If this should prove to be true, greater efficiency of excavation should be obtainable with the fluid tappet hammers which have a slower onset and longer force-time loading profile. Since this program will be the first to explore this and other aspects of continuous mining with impactors, we are indeed excited about this worthwhile effort.

\footnotetext{
*Strength, Fracture, and Workability of Coal, pg. 207, Pergamon Press, 1966.
} 
APPENDIX B

TEST MATRIX 
The testing will be in two parts; single hammer tests and three hammer array tests. The single hammer tests will be further divided into three parts. In this way, "homing in". of values for variables is attained to drastically reduce the size of a fully parametric test matrix. The test variable's are:
a. Tool. type
b. Angle of attack
c. Hammer type
d. Depth of cut
e.. Haulage (or preload) force
f. Blow energy
9. Array spacing.

In the first part of the single hammer test the tool type will be determined for the remainder of the matrix. The second part will cetermine angle of attack to be used with various depths of cut. This angle may or may not vary with depth of cut. The final part of the single hammer tests will compare two hammers, the Joy $411 \mathrm{~A}$ and the Contech HD-10. The most suitable will be used in the subsequent array tests.

The single hammer test variables will be as follows:
a. Two tool types - 12 in. spade and $4-1 / 2$ in. chisel
b. Three angles of attack - 10, 15 and 20 deg
c. Two hammer types - Joy $411 \mathrm{~A}$ and Contech HD-10\%
d. Three depths of cut $=8,16$ and 24 in.
e. Two haulage forces - 10,000 $\mathrm{Ib}$ and one other to be determined from test data
f. One blow energy value $-2,300 \mathrm{ft}-\mathrm{lb} / \mathrm{blow}$.*

\footnotetext{
*The single hammer tests wili be run at $2,30 \mathrm{C}$ ft-1b. " mi: for the contech HD-10. The Joy 4llA will be detuned to this value for the test.
} 


\section{B.1 Test 1}

Compare the $12 \mathrm{in}$. spade with the 4-1/2 in. chisel. On the basis of lesser specific energy for excavation one tool type will be chosen for the remainder of the single hammer and array tests in this material.

\begin{tabular}{|l|l|l|}
\hline & \multicolumn{1}{|c|}{ Run 1 } & \multicolumn{1}{|c|}{ Run 2} \\
\hline Tool type & $12 \mathrm{in.} \mathrm{spade}$ & $4-1 / 2 \mathrm{in.} \mathrm{chisel}$ \\
Angle of attack & $10 \mathrm{deg}$ & $10 \mathrm{deg}$ \\
Hammer type & Joy $411 \mathrm{~A}$ & Joy $41 \mathrm{~A}$ \\
Depth of cut & $16 \mathrm{in.}$ & $16 \mathrm{in.}$ \\
Haulage force & $10,000 \mathrm{lb}$ & $10,000 \mathrm{lb}$ \\
Blow energy & $2,300 \mathrm{ft-lb/blow}$ & $2,300 \mathrm{ft}-\mathrm{lb} / \mathrm{blow}$ \\
\hline
\end{tabular}

Measurements taken will be:

- Volume of material cut (by measuring weight and applying a known bulk density)

- Number of blows struck (by applying the known blow energy the total energy expended by the hammer is obtained)

- Haulage force, continuously integrated over distance run to give the energy expended by the haulage winch

- Time of run (to obtain average velocity and horsepower).

Specific energy for this configuration is obtained thus:

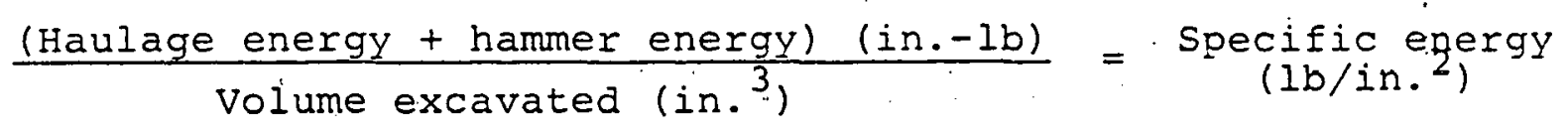

The lesser value will dictate the tool to be used in tinis material for the remainder of the test matrix. Other factors, not measured, but observed visually, may enter into the choice of tool. 


\section{B. 2 Test 2}

Compare the three angles of attack against the three depths of cut (Table $B-1$ ). This is to determine what angle of attack is most efficient for a given depth of cut. In subsequent tests that call for one value for angle of attack that angle will be determined by the depth of cut and the results of this test.

By taking the same measurements as test No. I a specific energy for each run is obtained. For each series (depth of cut) compare this value to determine the most efficient angle of attack. This angle will be used in combination with the corresponding depth of cut throughout the remainder of the test matrix. It should be noted that measured side load at various angles of attack will also be a deciding factor in the choice of angle. An angle indicating low specific energy but exhibiting high tool bending stresses is unacceptable.

TABLE B-1. - Comparison of depths of cut

\begin{tabular}{|c|c|c|c|}
\hline 8 in. Series & Run IA & Run 13 & Run $1 C$ \\
\hline $\begin{array}{l}\text { Depth of cut } \\
\text { Angle of attack } \\
\text { Hammer } \\
\text { Blow energy } \\
\text { Haulage force } \\
\text { Tool type }\end{array}$ & $\begin{array}{l}8 \text { in. } \\
10 \text { deg } \\
\text { Joy } 4 \text { lla } \\
2300 \text { ft-1b/olow } \\
10,000 \text { lb } \\
\text { Per test } 1\end{array}$ & $\begin{array}{l}8 \mathrm{in} . \\
15 \mathrm{deg} \\
\text { Joy } 411 \mathrm{~A} \\
2300 \text { ft-1b/blow } \\
10,000 \mathrm{~b} \\
\text { Per test } 1\end{array}$ & $\begin{array}{l}8 \text { in. } \\
20 \text { deg } \\
\text { Joy } 411 \mathrm{~A} \\
2300 \mathrm{ft}-1 \mathrm{~b} / \mathrm{blow} \\
10,000 \mathrm{lb} \\
\text { Per test } 1\end{array}$ \\
\hline 16 in. Series & Run 2A & Run 2B & Run $2 \mathrm{C}$ \\
\hline $\begin{array}{l}\text { Deptin of cut } \\
\text { Angle of attack } \\
\text { Hammer } \\
\text { Blow energy } \\
\text { Haulage force. } \\
\text { Tool type }\end{array}$ & $\begin{array}{l}\text { Repeat of } \\
\text { test } 1 \\
\text { run for } \\
\text { chosen tool }\end{array}$ & $\begin{array}{l}16 \text { in. } \\
15 \text { deg } \\
\text { Joy } 411 \mathrm{~A} \\
2300 \mathrm{ft}-1 \mathrm{~b} / \mathrm{blow} \\
10,000 \mathrm{lb} \\
\text { Per test } 1\end{array}$ & $\begin{array}{l}16 \text { in. } \\
20 \text { deg } \\
\text { Joy } 411 \mathrm{~A} \\
2300 \text { ft-1b/blow } \\
10,000 \text { lb } \\
\text { Per test } 1\end{array}$ \\
\hline 24 in. Series & Run 3A & Run 3B & Run $3 C$ \\
\hline $\begin{array}{l}\text { Depth of cut } \\
\text { Angle of attack } \\
\text { Hammer } \\
\text { Blow energy } \\
\text { Haulage force } \\
\text { Tool type }\end{array}$ & $\begin{array}{l}24 \text { in. } \\
10 \text { deg } \\
\text { Joy } 411 \mathrm{~A} \\
2300 \text { ft-1b/blow } \\
10,000 \text { lb } \\
\text { Per test } 1\end{array}$ & $\begin{array}{l}24 \mathrm{in} . \\
15 \mathrm{deg} \\
\text { Joy } 411 \mathrm{~A} \\
2300 \mathrm{ft}-1 \mathrm{~b} / \mathrm{bI} \text {.ow } \\
10,000 \mathrm{~b} \\
\text { Per test } 1\end{array}$ & 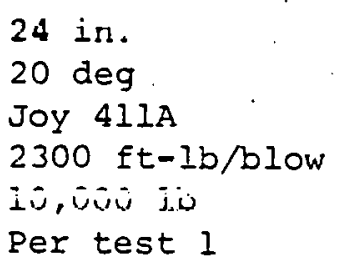 \\
\hline
\end{tabular}




\section{B. 3 Tests 3 and 4}

Tests 3 and 4 , as shown in Table $B-2$, are repeats of each other except test 3 will use the Joy $411 \mathrm{~A}$ hammer and test 4 will use the Contech HD-10 hammer. Each hammer will be tested using three depths of cut and two haulage forces.

In each case of the Joy $411 \mathrm{~A}$ and Contech HD-10 the second haulage force will be chosen by analyzing the results of the previous run. This value could be less than or more than the 10,000,1b previously used and will depend, largely, on visual observations of the process. The preload setting on the hammers (that load which causes the hammer to fire) must be adjusted to the haulage force.

By taking the same measurements as the previous tests a specific energy value can be derived for each of the 12 sets of conditions. The lowest value will indicate which hammer under which set of conditions is the most productive in this particular material. This hammer will be used for the array tests.

Total number of runs and subruns for single hammer tests equals 19.

\section{B. 4 Three-Hammer Array Tests}

Based on tests 1 through 4 the following constants have been established for the given material:
a. Tool type
b. Hammer type
c. Haulage force ( $3 x$ that for single hammer test)
d. Angle of attack for a given depth of cut.
The variables for the array tests are as follows:

a. Three depths oi cut $-8,16$ and 24 in. 
TABLE B-2. - Comparison of tests 3 and 4

\begin{tabular}{|c|c|c|c|}
\hline Test 3 & Run $1 A$ & Run IB & Run IC \\
\hline $\begin{array}{l}\text { Hammer type } \\
\text { Depth of cut } \\
\text { Haulage force } \\
\text { Angle of attack } \\
\text { Tool type } \\
\text { Slow energy }\end{array}$ & $\begin{array}{l}\text { Same as } \\
\text { test } 2 \\
\text { run } 1 \text { at } \\
\text { chosen angle }\end{array}$ & $\begin{array}{l}\text { Same as } \\
\text { test } 2 \\
\text { run } 2 \text { at } \\
\text { choser angle }\end{array}$ & $\begin{array}{l}\text { Same as } \\
\text { test } 2 \\
\text { run } 2 \text { at } \\
\text { chosen angle }\end{array}$ \\
\hline & Run 2A & Run 2B & Run $2 \mathrm{C}$ \\
\hline $\begin{array}{l}\text { Hammer: tyge } \\
\text { Depth of cut } \\
\text { Haulage force } \\
\text { Angle of attack } \\
\text { Tool type } \\
\text { Blow energy }\end{array}$ & $\begin{array}{l}\text { Joy } 411 \mathrm{~A} \\
8 \text { in. } \\
\text { * } \\
\text { Per test } 2 \text { run } 1 \\
\text { Per test } 1 \\
2300 \text { ft-lb/blow }\end{array}$ & $\begin{array}{l}\text { Joy } 411 \mathrm{~A} \\
16 \mathrm{in.} \\
\text { * } \\
\text { Per test } 2 \text { run } 2 \\
\text { Per test } 1 \\
2300 \mathrm{ft}-1 \mathrm{~b} / \mathrm{blow}\end{array}$ & $\begin{array}{l}\text { Joy } 411 \mathrm{~A} \\
24 \text { in. } \\
\text { * } \\
\text { Per test } 2 \text { run } 3 \\
\text { Per test } 1 \\
2300 \text { ft-lb/blow }\end{array}$ \\
\hline Test 4 & Run IA & . Run IB & Run IC \\
\hline $\begin{array}{l}\text { Hammer type } \\
\text { Depth of cut } \\
\text { Haulage force } \\
\text { Angle of attack } \\
\text { Tool type } \\
\text { Blow energy }\end{array}$ & $\begin{array}{l}\text { Contech HD-10 } \\
8 \text { in. } \\
10 ; 000 \text { Ib } \\
\text { Per test } 2 \text { run } 1 \\
\text { Per test } 1 \\
2300 \text { ft-1b/blow }\end{array}$ & $\begin{array}{l}\text { Contech HD-10 } \\
16 \text { in. } \\
10,000 \text { Ib } \\
\text { Per test } 2 \text { run } 2 \\
\text { Per test } 1 \\
2300 \text { ft }-1 \mathrm{~b} / \mathrm{blow}\end{array}$ & $\begin{array}{l}\text { Contech HD-10 } \\
24 \text { in.. } \\
10,000 \text { Ib } \\
\text { Per test } 2 \text { run } 3 \\
\text { Per test } 1 \\
2300 \text { ft-1b/blow }\end{array}$ \\
\hline . & . Run 2A & Run 2B & Run $2 C$ \\
\hline $\begin{array}{l}\text { Hammer type } \\
\text { Depth of cut } \\
\text { Haulage force } \\
\text { Angle of attack } \\
\text { Tool type } \\
\text { Blow energy }\end{array}$ & $\begin{array}{l}\text { Contech HD- } 10 \\
8 \text { in. } \\
\text { * } \\
\text { Per test } 2 \text { run } 1 \\
\text { Per test } 1 \\
2300 \text { ft-lb/blow }\end{array}$ & $\begin{array}{l}\text { Contech } \mathrm{HD}-10 \\
16 \text { in. } \\
\text { * } \\
\text { Per test } 2 \text { run } 2 \\
\text { Per test } 1 \\
2300 \text { ft-lb/blow }\end{array}$ & $\begin{array}{l}\text { Contech } 4 D-10 \\
24 \text { in. } \\
\star \\
\text { Per test } 2 \text { run } 3 \\
\text { Per test } 1 \\
2300 \text { ft-1b/blow }\end{array}$ \\
\hline
\end{tabular}

*To be determined on site based on test data and visual observations 
b. Three array spacings - 24, 36 and 48 in.

c. Two blow energy settings - *

B. 5 Test 5 - Array at 24 in. Spacing.

\begin{tabular}{|l|c|c|c|}
\hline & Run IA & Run 1B & Run 1C \\
\hline $\begin{array}{l}\text { Depth of cut } \\
\text { Blow energy }\end{array}$ & $\begin{array}{l}\text { 8 in. } \\
\text { First setting }\end{array}$ & $\begin{array}{l}16 \text { in. } \\
\text { First setting }\end{array}$ & $\begin{array}{l}24 \text { in. } \\
\text { First setting }\end{array}$ \\
\hline & Run 2A & Run 2B & Run 2C \\
\hline $\begin{array}{l}\text { Depth of cut } \\
\text { Blow energy }\end{array}$ & $\begin{array}{l}\text { S in. } \\
\text { Second setting }\end{array}$ & $\begin{array}{l}16 \text { in. } \\
\text { Second setting }\end{array}$ & $\begin{array}{l}21 \text { in. } \\
\text { Second setting }\end{array}$ \\
\hline
\end{tabular}

B. 6 Test 6 -Array at 36 in. Spacing

Repeat of test 5 with array at 36 in. spacing.

B. 7 Test 7 - Array at 48 in. Spacing

Repeat of test 5 with array at 48 in. spacing.

Total number of runs and subruns for array tests $=18$.

Specific energy values for each run and subrun will be obtained as before giving parametric data to indicate optimum values for the variables.

It should be noted that early in the testing certain extreme values (for example $20 \mathrm{deg}$ angle of attack, 24 in. depth of cut, or 48 in. array spacing) may be obviously unworkable and, therefore, can be eliminated from the matrix. Conversely, the data may indicate that extra values for the variables should be tried due to a trend in decreasing specific energy. Therefore, the actual number of single hammer and array tests $(19$ and 18 respectively) might well change.

\footnotetext{
* Should tine contech HD-10 be used in the array tests the two blow energy values will be the maximum (2300 ft-lb/blow) and one other, chosen by consideration of the previously obtained data. If the Joy $411 \mathrm{~A}$ hammer be used for the array tests the two blow energy values will probably. but not necessarily, be the maximum (4000 ft-lb/blow) and the previously used $2300 \mathrm{ft}-1 \mathrm{~b} / \mathrm{blow}$.
} 
The following test sequence is recommended:

First Mine Test Site

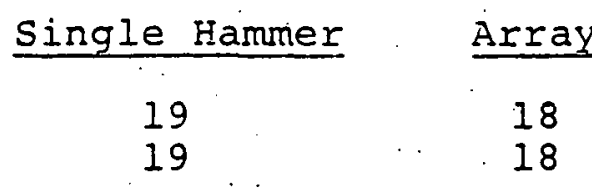

Second Mine Test Site

Coal

0

18

Rock

19

18

Hence, the total number of runs anticipated is 129.

Additional data recorded will be:

- Side loads on the tool

- Axial loads on the tool, which wili include firing preload and impulsive recoil

Still and motion pictures of the processes

Visual accounting of dust generation, rock size, noise and other pertinent conditions. 


\section{APPENDIX C}

REPORTS ON MINE VISITS 
Subject: Mine Visit to Colowyo Coal Company, Colorado

DATE: 17 January 1980

Colowyo Mine

Colowyo coal Company

P.O. Box 775

Craig, CO 81625

$303-82: 4-3474$

(Roughly $24 \mathrm{mi}$ s. of Craig, right side of Route 13)

Contacts: Ted Showalter

Tom Behling,

Mine Engineer

\section{C.1.1 Summary}

Mr. Showalter received our project and Tom Behling provided us with an excellent tour. Other engineers, including the President/General Manager Ira McKeever, who were originally scheduled to meet with us were otherwise occupied. A snow storm was brewing so that the review was kept short. More detailed information can be obtained via Mr: Showalter.

The Colowyo mine extracts 10 seams from a soon-to-be single pit. Seams and topography parallel one another with a grade of 10 percent. Mining proceeds up dip with an overall highwall slope of 70 percent (crest to toe). The pit is terraced, however not uniformally as in an open pit operation. Several truck-shovel operations take the stratagraphically higher overburden and coal, while a dragline deals with the lower seams. The pit length is $4000 \mathrm{ft}$.

Colowyo is still under development so a good Eix on pass times could not be established: Guessing from the number of terraces available, we should be able to fit in somewhere. Bench heights are 20 to 150 ft high, though lower heights could probably be found. Numerous outcrops abound. The geology is complex (relative to the Wyoming and Montana sites.) Fracturing or jointing is relatively frequent (localiy. 2 to $5 \mathrm{ft}$ spacing) and the strata is often thin. Picking a suitable site which combines all of the tests needs may. (again may not) be difficult. Climatic conditions in the winter would probably be quite discomforting for equipment and personnel.

Permission for testing will have to be through Mr. Mckeever. 


\section{C.1.2 Comments on the I/B}

Ted Showalter was the only one to review the impact breaker. His comments follow:

a. Track is preferable to tired undercarriagés.

b. The undercarriage would have to be well designed. They are experiencing problems with their shovels, due to a side hill operation.

c. The removal of partings would appear to be the best appliration.

d. Principal competition in terms of cost efficiency would be front end loaders and hydraulic excavators.

e. The system should be capable of cutting below grade, then along the side hill for bench work.

f. The system should be capable of cutting into corners.

9. MSHA will not allow working a highwall with a unit that is lower than slope height. The $I-R$ concept would have to cut the slope way back or be a gargantuan machine.

h. Scheduling haulage equipment to keep up with the I/B unit, whose bench haulage distance is rapidly changing would be difficult. Shovel systems are much more static and thorefore simpler to interface.

i. Should look at space requirements, turn radius, etc., if looking at benching (including trucks).

\section{C. . 3 Geology}

Unfortunately we häd little opportunity to inspect or discuss the geology of the pit. Ten seams are being mined simultaneously from a single pit. The pit is presently split into two pits, sepdraled by a huulrod. The two pits wore heveloped separately and there is some concern that the haulroad may be aligned on $a$ fault. If existing, the offsets across the two pits would only be 20 ft maximum. Interburdens are tough sandstones and moderate to soft shales. The haulroads are faced with locally quarried reddog which turns muddy when wet. Strata thickness can vary from 1 to 2 ft to massive, with sharp lithologic contacts. 
Jointing is well developed, subparallel to the strike of the pit. Joint spacing varies across the lithologies and can become as frequent as 1 ft. Local slips in the highwell and haulroads were evident. Several perched ground water tables drain into the spoil. Coal undulations or rolls occur occasionally reaching 10 percent grades (along the strike).

\section{C.1.4 Pit Layout}

Colowyo is still considered to be under development. Full production should be realized in early 1980. The pit length is 4000 ft and mining occurs up-dip. Topsoil is removed with front end loaders and j0-ton trucks. Self leveling scrapers have not worked due to boulders in the topsoil. The upper benches are removed. by truck-shovel operations. Rock haulage is presently done with 120 ton end dump Unit Rigs, while 20 more 170 -ton rock trucks are on order. The haulage circuit is 10,000 ft one way. The stripping shovels are one $\mathrm{M}-191$ and two $\mathrm{PH}-230013-1 / 2$ yd3 front end loaders load coal and supplement the shovels as. does a PH-1200 hydraulic excavator. Two BE draglines $(1300 \mathrm{~W}$, and $500 \mathrm{w}$ with 37 and 25 yd 3 buckets respectively) work the deeper section of the pit using the haulback method.

Blasting is accomplished with two $45, R$ BE drills, making 9-7/8 in. hole. A home made Simpco dual boom drill mounted on a BE cranebody drills coal. They have experienced overheating of the hydraulic system and air starvation to the drill tool. The unit can use either rotary or anger drills and the spacina between booms. is variable. They like the system alot, however, availability is only $50^{\circ}$ to 60 percent.

\section{c.2 Subject: Mine Visit to York Canyon, New Mexico}

DATE: 16 Jànuary 1980

York Canyon Mine

Kaiser Steel Corporation

P.O. Box. 1107

Raton, NM 87740

(505) 4.45-5531

Contacts: Mr. M. Durrance, General Superintendent, Strip Mine .

$$
\text { C.2.1 Summary }
$$

Mr. Durrance reviewed our project and toured the pit with us. He was extremely cooperative and invited us to consider York Canyon for a test site. Unfortunately, he is.considering retiring at the end of 1980 and he noted that he could not guarantee the 
cooperation of his heir. We were scheduled to talk witi tine chiej engineer, however he was sick that day. The property is split up by canyons and ridges so that a fair amount of jockeying of equipment takes place. Several areas of coal are uncovered for stockpiling purposes. A test site could take advantage of one of these stockpiling sites. The chief disadvantage of the York Canyon mine would be the relatively high fracture frequency and thinner strata. The coal is split up by partings which would mean a maximum coal test section thickness of $6 \mathrm{ft}$.

\section{C.2.2 comments on the $T_{i} / B$}

The Easi-Miner is operating in York Canyon to load coal. Mr. Durrance's comments are therefore backed with some experience in continuous surface miners.

a. The bottom-cut principle did not allow for natural blending of the coal. There is often a distinct vertical zonation of coal properties

b. A truck must wet down the coal to suppress dust. It would be nice if an integral dust suppression system could be incorporated into the miner

c. The Easi-Miner did not produce too many fines

d. A $50 \mathrm{ft}$ chute to get a $17 \mathrm{ft}$ clearance is needed; could cause tipping problems in some cases

e. Should produce 1000 to 1200 tons/hr; colncldent with theis biedkel unil

f. Spillage is not a problem with the spotting of trucks. The Easi-Miner stops forward movement while the trucks are changing out, though the cutting drum still turns

9. The Easi-Miner cuts faster than it needs to, though capable of $36 \mathrm{in.}$ the cut depth is 18 to $20 \mathrm{in}$.

h. The speed of advance is critical to the efficiency of the belt load, truck follow-up and power consumed

i. A spotter is required to see what the miner is cutting. A better system should be developed where the operators can determine what is happening

j. Due to seam rolls, cutting height should be variable 
k. Durrance feels that the overburden would be too tough for the I/B system. Feels machine would have to be too heavy

1. Grizzly size will not accept greater than 30 in.

m. A tire type undercarriage is better than track due to the increased flexibility. Unit Rig had some tractive force problems

n. The screw conveyor is viewed as a high dust, high maintenance item

o. There may be a problem loading the cut rock onto the belt

p. Does not see any advantage to making a flexible machine. If the unit works, it will be used all of the time. Cost and reliability will be the ultimate deciding factor. Efficiency, less so.

\section{c. 2.3 Geology}

The York Canyon mine extracts the York Canyon seam of the Raton formation (U. Cretaceous) and is 6 to $13 \mathrm{ft}$ thick. The seam is characterized as a metallurgical coking coal and is analyzed at 8 percent moisture, 7.5 percent ash, 0.5 percent sulfur and $14,340^{\circ}$ Btu. The York seam is essentially flat lying, however, the hilly topography severely interferes. in pit lavouts.

Present overburden depths are $70 \mathrm{ft}$, or a strip ratio of 6 to 1. The pit is presently approaching a hillside where the ratios projected reach 15 to 1 . A number of draws and burn areas presently divide the pit into smaller $1 / 4 \mathrm{mi}$ long pits. On the next pass the pits will join for a pit length of $1 \mathrm{mi}$. Overburden is a series of carbonaceous shales, siltstones and sandstones. Exposed sections indicated, strata thicknesses of 4 to $20 \mathrm{ft}$. Jointing appears to be frequent, however, they may be a result of blasting. The York seam is split by a $10 \mathrm{in}$. and 2 ft shale parting. The coal splits and coalesces along the pit strike. The sandstones appear moderate to hard, while the shales appear soft to moderate. The seam contains several 5 to 20 percent rolls. 


\section{2.4 Pit Layout}

The York seam is presently dissected by draws and burn areas. on the next pass the pits should link up to form a single, $1 \mathrm{mi}$ pit. As the pit approaches a hillside, a truck-shovel operation. cuts down the hillside to a more manageable height for the dragline. A 41 yd3.752 dragline (285 ft boom) operating off the highwall works the $150 \mathrm{ft}$ wide pit. As the overburden gets deeper the pit width will decrease to $110 \mathrm{ft}$. The overburden is shot with a Marion drill. A new drill will angle the holes 10 to $12 \mathrm{dcg}$ from the vertical. Coal is ripped by a D9 No. 41 single tooth, across the pit. Double teeth are too weak. Coal is loaded out with the Easi-Miner and $a$ 12-1/2 and 15 yaj front end loader. It looked like a narrow fender was left to stabilize the spoil. coal was hauled by 150 ton Tenex bottom dumps.

\section{C.3 Subject: Mine Visit to Chinook Mine; Indiana}

DATE: 16 January 1980

Chinook Mine

AMAX Coal Company

P.O. BOX 8

Staunton, IN 47881

812-894-2385

(Approximately $20 \mathrm{mi}$ east of Terre Haute, off $\mathrm{I}-70$ )

Contacts: Levi Rigney, Manager Mid-West Operations

Dale Teeters, Mine Manager

\section{C.3.1 summary}

our interview and mine tour involved the above two gentiemen who brought forth a substantial amount of experience. Both. Were very cooperative, especially considering the value of either one's time.

The Chinook mine operates two pits with an average strip ratio of 26 to 1. Pit widths varied from 70 to 150 ft and lengths were about $1 \mathrm{mi}$. A glacial outwash channel intersected the southern pit, effectively dividing it into three subpits. Six seams are mined between the two pits. This all makes for tight scheduling and congested areas. 
The six seams mined were $1,1.2,1,1.1,3.1$, and 2 ft thick. The overburden was in places very hard although the strata associated with the coal was relatively thin, and tended to pinch and coalesce. Finding a thick, consistent test section would be extremely difficult, however, it would be an excellent "tough". test case. In addition, the pits were subject to water inundations along low spots in the pit.

\section{C.3.2 Comments on the I/B Concept}

The following comments were forwarded by Mr. Rigney and Mr. Teeters:

a. Felt there may be some thrust problems in the harder overburden

b. They liked the ability to cut below grade because wider cuts may be used and it is easier to transport rock

c. It should work well in truck-shovel operations. Suggested we look at some around Gillette

d. May be of some use where coal freezing is a problem. to replace the "headache" ball

e. Suggested that. a tough test case could be found in some of the west Kentucky surface mines, where a $7 \mathrm{ft}$ limestone parting is ripped. with a core ripper

f. : A backhoe and hammer were tried on partings, but were too slow

9. They feel that the carriage would have to be extremely heavy to withstand the shock and vibration. This may cause a mobility and flotation problem on wet clay floors

h: Shooting the parting is a very high cost and safety problem. Congestion due to the many operations required was also a problem. The I/B concept would be of great help in parting removal

i An I/B with the ability to cut below qrade would be much more adaptable to present mining schemes

j. How the initial cuts would be made with the side cut scheme was questioned (box cuts) 
k. They liked the two-way cutting technique but were curious as to its utility in the corrers

1. The parting thicknesses vary considerably and the interfaces roll. Adjustable cut lengths will be required

m. Vertical joints intersecting the strike of the pit at a low angle may pull the cutters into the highwall

n. They felt that the scheme fit in besl wilh the leahy mire where a 45 ft parting is taken with a dragline

o. The I/B would have to compete against the shovel whlch is a relatively low cost item and has an 85 to 95 percent availability. Shovels are heavy, not stressed and do not have any small moving pieces

p. The pit should be started and finished without a drilier

q. If a thick, tough parting were encountered, the $I / B$ will need "a hell of a horse"

r. The I/B should cut out front instead of in the center like the Easi-Miner

s. Should be able to produce approximately 2000 tons/hr nT. $1000 \mathrm{yd} 3 / \mathrm{hr}$

t. They go after an $18 \mathrm{in.} \mathrm{seam} \mathrm{with} \mathrm{a} 3$ in. to 2 ft parting overlying it. The cutting mechanism should therefore be good to a 3 in. cutting accuracy

u. An electric system would be nice due to high diesel costs

\section{c. 3.3 Geology}

The Chinook mine accesses the No. 3 seam (Seelyville fm., lower Pennsylvania), and five other minor seams for an accumulated thickness of 86 in. The No. 3 seam is analyzed as 11.3 percent moisture, 11.2 percent ash, 3.05 percent sulfur and 11,080 Btu. Partings between seams range from 3 in. to 45 ft. Partings may be shales to limey shale and often must be blasted. Overburden is principally friable sandstones,. shales and a very tough limey shale. Jointing is infrequent, intersecting the pit at low, 
vertical angles. Seam, parting and overburden strata lense Erequently, and $10 \mathrm{ft}$ rolls in $200 \mathrm{ft}$ are not uncommon. Six seams are mined with $1,1.2,1,1.1,3.1$ and 2 ft thicknesses. The variability in geologi requires a final exploration grid of $120 \mathrm{ft}$. A glacial outwash channel intersects the southern pit at the midpoint and is about $1200 \mathrm{ft}$ across and 50 to 80 ft deep. The channel is a natural aquifer which, with its unconsolidated nature, causes highwall instabilities. Water must be pumped from the oit floors. Top soil is 4 to $10 \mathrm{ft}$ thick.

\section{3.4 Pit Layout}

The Chinook mine is divided into two pits (north and south). Pit lengths are approximately $\mathrm{I} \mathrm{mi}$ long and 80 to $110 \mathrm{ft}$ deep. Strip ratios are 30 and 25 or an average of 26 to 1 . Mining occurs 364 days a year, three shifts per day in overburden, and two shifts per day in coal. Pit widths vary from $70 \mathrm{ft}$ in the southern pit to $150 \mathrm{ft}$ in the northern pit. Drag lines with 85 yd 3 buckets sidecast the majority of overburden and thicker ( 7 to $10 \mathrm{ft}$ ) parting.s. An $11 \mathrm{yd}^{3}$ Marion 151 and a $12 \mathrm{yd}^{3}$ Marion 182 shovel work in the pit loading coal and placing the interburden in $60 \mathrm{ft}$ high spoils. A 15 to $20 \mathrm{ft}$ fender is often' left to stabilize the spoil stacked by the shovels. Haulroads are on the parting or coal while the shovel works on the pit floor. Spoil slopes are $1-1 / 4$ to 1 ; spoil swells 25 percent.

Overburden is drilled with BE $60 \mathrm{R}$ drills, 15 in. holes. Powder factors are generally $0.5 \mathrm{lb} / \mathrm{yd}^{3}$. for overburden and $0.17 \mathrm{Ib} / \mathrm{yd}^{3}$ for the parting. Parting is shot through $6-1 / 2$ in. holes and is considered a high cost operation. Coal is ripped with a single tooth $D-9$.

Haulage ramps out of the southern pit go through the spoil while the northern pit cuts its ramps into the highwall. They have 19 scrapers to remove top soil and for reclamation. Top soil becomes extremely soft in the wet seasons such that lightweight D-6's have flotation problems. 
C.4 Subject: Mine Visit to the Navajo Mine, New Mexico

DATE: 16 January 1980

Navajo Mine

Utah International, Inc.

P.O. Box ' 155

Fruitland, NM 87416

505-598-5861

Contacts: Mr. Wes Karna, Mine Engineer

$$
\text { C. } 4.1 \text { Summary }
$$

Vehicle problems with our rental forced us to be late for our interview. Unfortunately, Mr. Karna had a tight schedule which resulted in a short session. Our interview consisted of Mr. Karna and several other staff engineers. Our mine tour unfortunately was led by an engineer who apparently had not been to the pits in a long time. The engineers were very cooperative and Mr. Karna agreed that we should request a letter of confirmation for the test program. Navajo has four pits each.with different seams, and overburdens. The overburden is uniform and soft. Partings up to $10 \mathrm{ft}$ thick exist in some pits. Coal is not exposed in outcrops, however, pit lengths are $2 \mathrm{mi}$ allowing for ample test times. The engineers noted that the caprock on the mesas were difficult to comminute and would provide a good overburden test. Climatic conditions are moderate year round.

$$
\text { C. } 4.2 \text { Comments on } I / B
$$

Comments or questions on the impact breaker system follow:

a. The Engineers were curious as to how a pit would be started. The $I / B$ must be side cutting on both sides and capable of cutting below grade, for box cuts. cut rock must be transported out of a box cut in some fashion.

b. Anaconda experimented with a machinc using hydraulic impactors. The hoses all broke because of the shock transfer.

c. The screw conveyor would be a high maintenance item arid cause too much dust. 
a. They feel the I/B would fit in well with a truck-shovel operation.

e. They liked the Melrose power train, especially the mobility.

f. The $I / B$ should work well where multiple seam mining is occurring. They presently use a dragline if the parting is greater than $10 \mathrm{ft}$.

9. They like cutting below grade better than the side wall plow concept.

h. There is no water in the pit and dust is a severe problem. Should incorporate a dust suppression system.

i. They do not feel that their drill-blast cycle is very expensive.

\section{4.3 Geology}

The Navajo mine principally extracts the No. 6, 7, and 8 seams of the Fruitland formation in the Navajo field. Eight seams are mined in total. Four pits operate on the property, each accessing a different seam with unique properties. Overall blend results in 13.2 percent moisture, 0.72 percent sulfur, and 9200 Btu. Though the seams are relatively flat lying, 4 ft rolls every $100 \mathrm{ft}$ or so are common. The overburden is generally soft al-.. though lenses of hard sandstone occur within the overburden and as caprock for the mesas. Spontaneous combustion of the coal is common and occurs even within the highwall.

$$
\text { C. } 4.4 \text { Pit Layout }
$$

Four pits operate at the Navajo mine. Three BE 1350W, $50 \mathrm{yd}^{3}, 285 \mathrm{ft}$ boom draglines open up pits with $100 \mathrm{ft}$ wide floors, using the extended bench method. Pit lengths average $2 \mathrm{mi}$. Front end loaders load the coal into WABCO 120-ton bottom dumps. 


\section{C.5 Subject: Mine Visit to Jim Bridger Mine}

\section{DATE: 14 January 1980}

Jim Bridger Mine

Jim Bridger Coal Co.

Rock Springs, WY 82901

307-382-9741

I-80 E, from Rock Springs. Point of Rocks exit, under I-80, right, approximately $4 \mathrm{mi}$ to power plant. Mine office on NE side of plant.

Contacts: Mark L. Bricker, Assistant Mine Engineer

Glan Goss, Mine Manager

Steve Biel, Chief Engineer

Gary Yoakum, Mine Engineer

\section{C.5.1 Summary}

The impact of our meeting at Jim Bridger was blunted by the absence of the Chief Engineers. Our talks involved only assistant mining engineers who, though helpful, would not comment on the impact breaker concept. Information gathered was therefore limited to their own operation. If we decide to try Jim Bridger we must make a personal presentation to Steve Biel, Chief Engineer. 'The likelihood of cooperation is unknown.

The Jim Bridger mine is a large captive operation feeding the the three unit Jim Bridger power plant at a rate of $5.5 \mathrm{MM}$ tons/hr. There are presently two pits, $6 \mathrm{mi}$ in length (total). They are eventually going to connect the pits together and possibly extend south to have an overall pit length of $9 \mathrm{mi}$. Only one seam (the Deadman) is mined, however a sandy shale parting requires a separate blast-haulage cycle. The pit is plagued by occasional water inundations. The highwall consists of sandstones, siltstones and shales ranging from soft to moderately hard. Overburden is presently 80 ft deep, although the expected pit limits will encounter $250 \mathrm{ft}$ depths. It would appear. that if a block of coal is left for testing, the area would not be interfered with for some time. Geologically, the site would be relatively eary to moderate. Finding an area to test the overburden may be difficult. 


\section{C.5.2. Comments on the $I / B$}

The only comments that we could solicit on the advantages and disadvantages of the $I / B$ concept were that if it worked, cutting off of the floor, it would help a lot with parting removal, and possibly on haulroad maintenance. He liked the tire concept, but questioned the increased maintenance, operator and fuel cost required to transport cut overburden. Could see a use in truck-shovel operations. Would like to see a dust suppression system incorporated.

\section{C.5.3 Geology}

The Jim Bridger mine is extracting the Deadman seam, which is 25 to $30 \mathrm{ft}$ thick. Typical analysis indicates 20.5 percent moisture, 9.7 percent ash, 0.47 percent sulfur, and 9350 Btu/lb. The seam splits in local areas into a 2 to $3 \mathrm{ft}$ lower seam. The parting is a sandy siltstone which locally gets up to 40 ft thick: The parting becomes slippery when wet. The Deadman seam dips 2 to $5 \mathrm{deg}$ to the east. so that the present overburden of $80 \mathrm{ft}$ will increase to 250 ft at the pit limits. A large burn area presently splits the seam into two separate pits. The topography is flat. The overburden is a series of siltstones, clayey shale, carbonaceous shales, and sandstones varying from soft to moderately hard. Coal is flaggy to slabby, cleat is poorly developed. Occasional boulders in the topsoil of up to $10 \mathrm{ft}$ in diameter complicate scraper haulage. The overburden is relatively competent with vertical jointing occurring at roughly 5 to io ft intervals. Perched water tables have caused local flooding as much as 6 ft deep. Water is pumped back into the spoil area. Further details of the site geology or hydrology can be obtained from Bill Gerhart at the corporate office in Portland, OR.

\section{C.5.4 Pit Layout}

Coal production at the pit is 20,000 tons/day on a two shift basis. A Marion 8200, Page 757 and a Page 732 dragiine are being used with 72,60 and $20 \mathrm{yd}^{3}$. buckets and 315,326 and $225 \mathrm{ft}$ booms, respectively. Pit widths vary from 110 to $180 \mathrm{ft}$ and the extended bench method was used at the pit we visited. Eventually a haul-back method will be used. A 5 ft coal berm and fender was left to stabilize the spoil toe. Overall recovery was 95 to 98 percent. The fender was reclaimed with a hydraulic excavator whenever possible. Haulroads are through the spoil. Ramps are 7 percent while roads are at a maximum of 3 percent grade. Belts are being considered for coal transportation to the blending facilities at the plant. Cut coal gets up to $4 \mathrm{ft}$ slabs. The $60 \mathrm{R}$ $B E$ drills, 12-3/4 in. diam.holes are used for burden blasting. 
Coal is loaded with two $18 \mathrm{yd}^{3} \mathrm{BE}$ shovels or a $15 \mathrm{yd}^{3}$ front end loader. The front end loader generally handles the parting unless it is too thick, whereupon the dragline takes over. On occasion the parting is ripped and a scraper hauls out the parting. Haulage is with twelve, 120 -ton WABCO $85 \mathrm{C}$ 's and four, 85-ton WABCO end dumps. Tractored vehicles are kept off of the coal, while the other vehicles are kept off of the poor floor. Reclamation is accomplished with $\mathrm{D}-95$ and WABCO and Terex 24 to $28 \mathrm{yd}^{3}$ scrapers.

\section{6 Subject: Mine Visit to Energy Fuels Mine}

Date: 11 January 1980

Energy Fuels

P.O. Box 6

Steamboat Springs, CO 80477

303-879-3800

(roughly $20 \mathrm{mi}$.southwest of steamboat, can be reached via

Hayden also)

Contacts: Gib Lazor, Production Superintendent

Summary

Mr. Lazor's only comment on the impact breaker concept (I/B) was that he could not see how it could do better than what he had. Considering his mining situation that is probably true. Two seams are mined, the wedge (96 in. thick) and the Fish Creek (4 ft thick) in three to five pits. Both seams dip 10 to 16 deg to the north with the overburden varying from 20 to $120 \mathrm{ft}$, or an overall strip ratio of 8.5 to 1 .

The geology is simple with no partings, significant cleat or problem strata. Robbins and $I-R$ drills sink $9-7 / 8$ in. or 7-7/8 in. diam blast holes depending on cover depth. Drill patterns vary between $16 \times 16 \mathrm{ft}$ to $21 \times 21 \mathrm{ft}$.

Three draglines are presently used in 14, 21, and 55. yd ${ }^{3}$ buckets. The $55 \mathrm{yd}^{3}$ is a Marion $8050,325 \mathrm{ft}^{3}$ boom. An $8 \mathrm{yd}^{3}$ dragline removes overburden to $30 \%$ ft depth, the 14 and $21 \mathrm{yd}^{3}$ draglines clean to $120 \mathrm{ft}$. Pits work up-dig, and permit restrictions have constrained pit limits" to $2000 \mathrm{ft}$. Pit floors are 100 ft wide. L-80 loaders with 20 yd 3 buckets load 50 ton bottom dump Euclids; and Goodberry 100, 175's. Obtaining sufficient loading height is sometimes a problem due to the high grade in the pit. A snovel is used for box cuts. Where overburden is less than 30 ft a scraper-loader/dozer team handles overburden removal. EFC is probably a dim candidate for testing. 


\section{C.7 Subject: Mine Visit to the Trapper Mine}

Date: 11 January 1980

Trapper Mine

Utah International

P.O. BOX 187

Craig, CO 81625

$303-824-4401$

(approximately 6-1/2 $\mathrm{mi} \mathrm{s}$. of Craig off Rt. 13)

Contacts: John Pollard; Manager Surface Operations

R. Diederich, Mine Manager

R. Leitzman, Assistant Mine Manager

T. Maclean, General Mine Foreman

Several Others

\section{C.7.1 summary}

Oru principal contact was John Pollard. We met with the entire engineering staff, who reviewed our project and made the comments noted below. The operation has 3 pits (Enfield Derringer, Ashmore), multiple seams, and is steeply pitching (16 percent). Climatic conditions limit the number of months topsoil can be handled ( 3 to 5 out of the year). Pit lengths are limited to 1 mile maximum (Derringer pit) reducing to $1800 \mathrm{ft}$ in the Ashmore pit. Extreme care is required of scheduling procedures, with several operations going on in a pit at a given time. Friendly cooperation with the engineers would be anticipated for any testing program. The mine is a captive operation supplying the plant with $2.7 \mathrm{MM}$ tons/year (MTPY). Outcrops abound so that overburden testing would be simple, however, the coal tests would require severe constraints in the scheduling. This infers that Trapper would be a poor to moderate cholce. The mine engineers suggested we test the system at their Cedar City, UT, iron ore mine (York Jones is mine manager).

Geologically the Trapper mine offers a variety of conditions. The seams dip 14 to 20 percent. Four seams are mined (only two per pit), however, several thin 2 to 4 in. riders exist which are mixed in with the parting and lost. They have an interburden or parting problem requiring supplemental blasting. Cleat and joint orientation is significant enough that they try to align the blastholes parallel to the principal cleat orientation (down dip). A sandstone ledge has been hard enough to cause problems. Except for the grade and relatively frequent joint spacing (5 to $10 \mathrm{ft}$ ) the site would be good to excellent for testing. 
Climatically the winter's become $-450 \mathrm{~F}$. with up to 6 ft of snow. The fall and spring are wet and slippery. The pits are exposed to high winds. Climatically the site would be lousy for testing other than the summer, late spring or early fall.

\section{C.7.2 Comments of $\mathrm{I} / \mathrm{B}$}

Comments from the impact breaker design review follow:

a. Srrew conveyors are viewed as a high maintenance problem, creates too much dust.

b. The spacing of the impact breakers may be critical they may need to be adjustable for each lithology or pass.

c. A power take off of a Cummings engine was viewed favorably.

d. The I/B system should fit in with a truck-shovel operation best.

e They were concerned over the cut height flexibility especially considering seam height variations.

f. They thought spades were better than bull pricks.

g. They were concerned that the unit be able to traverse 20 percent grades (not including local irregularities).

h. Considering the grades encountered, the spectre of high tipping moments are noted, especially with the extended transfer chutes.

i. Should be good for parting removal - they saw a real need. It would be well worth it if the unit could simultaneously split out thin ( 3 to 6 in.) riders from partings.

j. The cutting head should be capable of cutting below or above grade.

k. The transfer chute idea was okay. They saw it as dropping windrows rather than direct loading. They use end dumps rather than bottom dumps.

1. They thought we would be forced to go to track rather than rubber tired (Easi-Miner worked well). 
m. The unit should be capable of sumping into corners, and operating in both directions.

n. Could see a use for water trenching. The Easi-Miner was so utilized.

o. The Easi-Miner had lots of hydraulic problems particularly in the winter. They emphasized that any vehicle including the testing - must be winterized.

p. Noise may be a problem.

q. Should determine the wear on the impactors.

r. The I/B may have too much horsepower.

s. Must look at availability of continuous use.

t. Asked whether we had investigated mechanical cam action impact breakers such as the Ken:- tools.

u. They liked the Holland Loader in the Shirley Basin, however, if one Cat was down, the whole unit is inoperable.

v. Could be used as a clean up tool, partings, haulroads, ramps.

w. Iiked small Unit Rig, not larger version.

x. Teeth change for the Easi-Miner was $4 \mathrm{hr}$ - what would be maintenance time on the I/B?

y. Should produce 10,000 tons/day (TPD) in coal, 10,000 $\mathrm{yd}^{3}$ per shift in overburden.

\section{7.3 Geology}

The Trapper mine is located along the northern flank of the Williams Dork Mountains, forming the southern limb of the eastwest striking Sand Wash synclinorium (or northern limb of the Williams Fork anticline, or the southern limb of the Big Bottom syncline). The crest of the mountains form the southern property boundary. Four seams are presently mined $H, I, Q$, and $R$, all belonging to the Williams Fork formation of the Cretaceous age. The upper $H$ and $I$ seams are only present in the northern portion of the property. Thicknesses are 5 to 9 ft respectively, characterized by 10,100 to 10,200 Btu's, 0.45 percent $s, 16$ percent moisture, and 10 percent ash. Roughly 40 ft of sandstone and shale separate the $H$ and $I$ seams. The $Q$ and $R$ seams are mined 
in the southern section of the property and are $100 \mathrm{ft}$ below seam I. The $Q$ seam ranges in thickness from 8 to $13 \mathrm{ft}$ with a 1 ft shale parting near the top, and the $R$ seam splits in to $R_{1}=3 \mathrm{ft}$ and $R_{2}=2 \mathrm{ft}$. The $\mathrm{R}$ parting can reach up to $10 \mathrm{ft}$ thick of shale and siltstone. Seam separations of the $R$ and $Q$ seams vary from 40 ft up-dip, thinning down-dip. The $R$ and $Q$ coal is characterized by 9600 to 9900 Btu's. The coal is blended at the power plant. The average slope of the surface is 10 percent, with local rolls of up to 20 percent. Stripping depths vary according to the local geology but ranges from 20 to 150 ft. Several deeper seams are being considered for underground mining. Fracture evaluation. was difficult as UI uses a 200 ft blasted buffer zone along the highwall. Pit floors are fireclay.

\section{C.7.4 Pit Layout}

All three pits follow the same basic pattern. Topsoil is removed $600 \mathrm{ft}$ ahead of the dragline operation. Topsoil varies from 8 in. to $6 \mathrm{ft}$, averaging $2-1 / 2 \mathrm{ft}$. Two Joy RRI0 overburden drills mounted on Cat D9 tractors drill 10-5/8 in. diam holes. The schedule calls for 4,500 ft of hole every third day. Hole depths vary with location down to $140 \mathrm{ft}$. Trapper buffer blasts behind 200 ft of previously blasted overburden (no free face) to protect the dragline. Although the burden can be ripped by a D9, they do not like to. Coal drills are Joy dual booms, drilling 4 in. diam holes at a $12 \times 12$ ft spacing.

The draglines are all Page 752R's downrated from 42 yd $\mathrm{y}^{3}$ to $30 \mathrm{yd}^{3}$, in order to get a $3 \mathrm{us}^{\mathrm{ft}}$ boom or $285 \mathrm{ft}$ reach from the centerline. The draglines operate off of the highwall working down-dip. In the Ashmore and Enfield pits, the dragline dead heads up-dip and excavates down-dip when taking the interburden. In the longer Derringer pit, the dragline works up-dip and downdip. The draglines mine out the pad down-dip, turn around and mine the previous pad and then move down to the now excavated down-dip pad. This box cutting techrique makes for a gear tooth shaped highwall. The dragline works in an area 600 to 700 ft long, or $300 \mathrm{ft}$ down-dip and $300 \mathrm{ft}$ up-dip.

In the Derringer pit a parting between seams wedges from 40 ft up-dip to $10 \mathrm{ft}$ at the lower end of pit. The parting is blasted and removed by hydraulic excavators; and truck. When a 300 ft block of coal has been exposed it is removed (measured updip). Another 300 ft thick block of parting is blasted and pushed via dozer into the down-dip pit. This continues up-dip until the parting thickness reaches 25 ft (sometimes only $10 \mathrm{ft}$ ). The dragIine then walks over to the spoil side, builds out a pad and removes the parting working up-dip. 
Coal loading is accomplished by three Demag III $15 \mathrm{yd}^{3}$ hydrauIic excavators, operating off of the coal. They load into four, 50-ton Mack $45 \mathrm{Sx}$ end dumps, seven, 50-ton R50 Euclids, or two, 70-ton WABCO's, running on the floor. Two, 24-yd3 Terex scrapers remove topsoil. Ramps are located at either end of the pit and one at midpoint through the spoil in the Derringer pit. Ramp grades are 8 percent and haulroads are surfaced with locally mined red $\operatorname{dog}$.

\section{8 Subject: Mine Visit to Rosebud Mine}

Date: 10 January 1980

Rosebud Mine

Western Energy Co.

Colstrip, MT 59323

406-748-2326

(approximately $1 / 2 \mathrm{mi}$. S.W. of Colstrip, approximately $100 \mathrm{mi}$. E. of Billings)

Contacts: "Spec" Willis, Mine Superintendert, Long Construction Co.

The Rosebud mine is operated by Iong Construction Company owned by Western Energy Fuels, a subsidiary of Montana Power. The coal is shipped primarily to the nearby Colstrip power units, the Corette plant and several midwestern utilities in Minnesota, Wisconsin and North and South Dakota. The Rosebud seam of the Fort Union formation (Cretaceous) is the only seam mined. It averages 22 to $24 \mathrm{ft}$ thick, and is characterized as 8700 Btu, 25 percent moisture, 9 percent ash, 0.8 percent $S$. The overburden averages, $100 \mathrm{ft}$ thick, is primarily soft to medium hard, siltstones, sandstones, with some shale.

Our interview was with spec Willis, mine superintendent of Long Construction Company. His background is large earth moving projects, which he perceives open pit mining to be. spec was respectfully cooperative although any real power is wielded by the management of Western Energy in Billings. Spec gave us a detailed rundown of the operation, however, we did not get a guided mine visit. Arrangements must be made with Western Energy, and due to our time limitations, we were not able to do so. Spec indicated that he would not be happy with a test program in his pit. However, he did not seem to be the vindictive type. Cooperation wise, Rosebud could be classified as moderate.

The mining operation at Rosebud is severely limited by permit restrictions. The operation is split up into three pits, two 
(spacing 5 to $20 \mathrm{ft}$ ). A 30 to 40 ft thick shale - "sandrock" caprock overlies the coal, and a fireclay floor becomes slippery when wet.

\section{8.2 Pit Layout}

The Rosebud mine has been segmented into three pits ( $A, B$, E) due to permit restrictions. Pit lengths are limited to roughly 3,000 ft, chevron shaped. Overall stripping ratios are 3.5 to 1 . Two of the pits $(A$ and $E$ ) are dragline pits, while the third uses a new concept of stripping scrapers. The operations run 7 days a week, 3 shifts.

Pit $A$ and $E$ are the highest producers, using two Marion 8050 draglines with $60 \mathrm{yd}^{3}$ buckets. Boom lengths are $325 \mathrm{ft}$, and they load $4000 \mathrm{yd} 3 / \mathrm{hr}$ on the average, $5000 \mathrm{yd} 3 / \mathrm{hr}$ on a good day. An old Marion 360 helps out at the E pit, while a BE 1050, $24 \mathrm{yd}^{3}$ bucket helps at pit A. Pit floors are 170 to $250 \mathrm{ft}$ wide. 20 ft of coal is often left at the base of the spoil to act as a fender reducing recovery to 90 percent. Haulroads extend through the spoil.

Pit $A$ uses a BE280B loading shovel, pit E uses a BE550, and Pit $B$ uses a BE250B behind the scraper operation. The loading shovels have $17 \mathrm{yd}^{3}$ buckets, although spec requested $22 \mathrm{yd}^{3}$. Coal is taken in a single pass (no lifts), at a rate of 1000 tons/ hr. Tipple capacity is 4000 tons/hr. No requirements or:problems exist with coal size. Primary crushers take the coal down to -3 in. The coal is loaded into thirteen, 120-ton bottom dump Euclids, two Cat 660's and one cat 666.' Conveyors were considered, however, a German firm said that the environment was too abrasive. Tire life is apparently very short, lasting an average of $600 \mathrm{hr}$.

Overburden is shot with two BE60R, and one BE45R. Holes are $15 \mathrm{in}$. diam, burden $35 \mathrm{ft}$, spacing $40 \mathrm{ft}$ all shot with ANFO. The burden ratio was $0.35 / 100$ yd $0 . B$. Three failing rigs, drilling 6 in. holes are used for coal. All of the burden can be ripped, although a shale caprock is marginal.

Pit $B$ is presently using a scraper stripping technique with four, Cat $637 \mathrm{D}$ tandem powered push/pull scrapers, and two, D\&H dozers. The pit is up to $160 \mathrm{ft}$ deep, $1300 \mathrm{ft}$ long, and 150 to 200 ft wide. The dozers create a haul ramp, the scraper teams run down the ramps, picking up their load, and continue across the pit to dump in the reclamation area. Cycle times are $3-1 / 2$ to $4-1 / 2 \mathrm{~min}$, moving 260 to $280 \mathrm{ya}^{3}$. 


\section{8.3 Western Energy Co.}

North Western Resources Co.

$404 \mathrm{~N}$. 3lst St.

Bilings, MT 59101

$406-252-2277$

Contacts: Roger C. Rice, V.P. Resources

Tim Wood, Manager - Planning.

Spec Willis had suggested we talk to Art Niel at Western Energy. Mr. Niel is in charge of production and would have ultimate say over permission for testing. Mr. Niel was not in so we talked to $\mathrm{Mr}$. Rice and $\mathrm{Mr}$. Wood. We reviewed the project with them. Their comments paralleled specs. They thought diesel costs would be high, especially with the additional trucks required for overburden handiing. They thought it had potential in thin seam mines, mines with partings, and shovel-truck operations. They could not see how it could be used at Rosebud or even tested at Rosebud due to the short pit lengths. They would talk with Art Niel. There was a possibility of using it at a smaller mine such as at Grass Creek, MT.

Subsequent telephone conversations were that Art Niel could not see "why they should bother," but would talk to us personally if we wanted. No further action taken as of 9 January 1980 .

\section{C.9 Subject: Tracking Down the Phantom Mines Interviewed by Skelly \& Loy (S\&L) for the Ingersoll-Rand (I-R) Report on Continuous Surface Mining Machines}

Date: 12 March 1980

There were two sets of unknown mines in the $I-R$ report. The first set included six mines purportedly interviewed by $S \& I$ for the purposes of soliciting comments and commitments for testing of a continuous surface mining (CSM) machine (pages 63-66 I-R report). The second list (pages 213-231) involved operational particulars for the purpose of performing an economic analysis on the various CSM concepts.

In order to insure that FMA had contacted all parties even partialiy interested in sponsoring a field test on their property, an attempt was made to identify and contact the above mentioned mine sites. The following list is the result of the identification process. Mines $C$ and $D$ were difficult to identify, however, in the $I-R$ report they also appearea to express very little enthusiasm for cooperation. Mine A or Energy Fuels 
using $60 \mathrm{yd}^{2}$ araglines (BE8050's), backed up by a Marion 360 (pits $A, E)$, and a scraper stripping operation (pit B). The pits move quickly inferring that test times would be short. Highwalls were $100 \mathrm{ft}$ to $270 \mathrm{ft}$ high, 1 to $1 / 4$ slope, haulroads spaced through the spoil. Finding a location to run a test in coal would be difficult, however, outcrops in the form of low ridges could be used for overburden tests. In terms of interfacing with the present operation, Rosebud would be a difficult to moderate location. The overburden appears to be relatively soft. Few fractures and boulders exist. All of it can be ripped, howcver, it is blastcd. From the very little that we saw, the strata was continuous and thick. The rock appeared to decompose or break up rapidly after blasting and handing. Geologically this should be an "easy" test site.

Comments on the impact breakers concept were:

a. Material transport would be difficult. Hard to beat the dual function of the dragline.

b. The machine must be capable of cutting below grade.

c. The machine should be capable of operating in the corners.

d. Interested in seeing what the traction-thrust behavior would be in wet fine clay.

e. Iiked rubber better than track.

i. Néded to be tlexible in cuttıng herght.

9. Probably no good in the overburden...

h. Possibly of use in coal, especially when partings were present.

\section{C.8.1 Geology}

The coal is Rosebud seam, 22. to 24 ft thick, no parting, flat lying. Overburden 100 to $270 \mathrm{ft} \mathrm{high,} \mathrm{average} 100 \mathrm{ft}$, of soft to medium hard sandstones, siltstones, and shale. Close inspection was not possible, however, the contacts appeared to be gradational, varying \pm 10 ft over 3,000 ft pit length. Outcrops contained isolated hard shale lenses, $10 \times 2 \mathrm{ft}$. Isolated sandstone ridges raise overburden. heights to elevations greater than $100 \mathrm{ft}$. No significant cleat or jointing was visible 
near Steamboat Springs which was visited during the FMA tour. We must have talked to someone else as the reception to our probe was friendly, however, firm, that CSM's were not to be considered at that mine.

Mine $B$ is probably the seneca mine which feeds the Hayden power plant. Although we had not given them any warning of our visit it was apparent that it would not have mattered much if we had written in advance. Judging from the brief paragraph in the $I-R$ report, $S \& L$ received the same reception.

Mine $E$ is probably equivalent to the Belle Ayre mine by Gillette, WY. Kort Morgan, the mine manager expressed several reservations of the CSM concept, however, was receptive to a more detailed design review. Letters were sent to Mr. Morgan with that regard.

Mine $F$ or the Wyodak mine appeared interested in the I-R report. However, following up on the lead it was discovered that Wyodak did not need to drill and blast the overburden, as it was presently scraped. This would not appear to be a relevant geology for testing of the CSM. A letter detailing our plans was sent regardless:

a. Mine $A=$ Energy Fuels (Colorado)

1. In I-R report appeared interested

2. In FMA interview was not interested

b. Mine $B=$ Seneca (Colorado)

1. No interest in $I-R$ report

2. No interest in FMA interview

c. Mine $\mathrm{C}=$ Rosebud (Wyoming) or Resource Exploration

1. Little interest expressed in $I-R$ report

2. Not contacted by FMA

d. Mine $D=$ Arch Minerals - Seminoe Mine

1. Iittle interest expressed in I-R report

2. Not contacted by FMA 
e. inine $E=A I A X$ - Belle Ayre

1. Appeared interested in $I-R$ report

2. Contact in process by FMA

f. Mine $F$ - Wyodak

1. Appeared interested in $I-R$ report

2. Contact in process by FMA.

None of the mines noted in the $I-R$ economic analysis (pages 213-23I I-R report) were actively soucht although it is possible that if Mine No. 9 is the Jim Bridger mine it was contarter.

a. No. 1, Illinois, AMAX: Leahy, Peabody: No. 10, Rinerking, S.W. Ill. Coal Corp: Captain Mine

b. No. 2, Montana, Decker Coal or Colstrip

c. No. 3, Wyoming, Kemmener Coal: Sorenson Mine or Pacific Power and Light: Dave Johnston. Mine

d. No. 4, N. Dakota, N. American: Sudran Head Mine

e. No. 5, Wyoming, Arch Minerals

f. No. 6, Arizona, Peabody, Black Mesa/Kayenta

g. No. 7, N. Dakota, Consol: Velva Mine

h. No. 8, Montana, Westmorland Resource: Sarpy Creek

i. No. 9, Wyoming, Jim Bridger - maybe

j. No. 10, Washington, Centralia Mine. 